\title{
Translocal Anglo-India and the Multilingual Reading Public
}

\author{
JAMES MULHOLLAND
}

JAMES MULHOLLAND is associate professor of English at North Carolina State University. An expanded version of this article can be found in Before the Raj: Writing Early Anglophone India, forthcoming from Johns Hopkins University Press. $\mathrm{He}$ is also the author of Sounding Imperial: Poetic Voice and the Politics of Empire, 1730-1820 (Johns Hopkins UP, 2013).
T HE FUTURE OF ANGLOPHONE LITERARY STUDIES MIGHT BE FOUND in Asia. According to Gauri Viswanathan, the discipline of English began there with the training of early-nineteenthcentury colonial administrators and was adopted only decades later in Great Britain (2-3). Since her account, our understanding of cultural production before the British Raj has only improved. Scholars have turned to assessing the social and political contexts of anglophone authors, while archivists have added detailed histories of printing in India and demonstrated the importance of writing for international commerce. ${ }^{1}$ Examinations of the Indian Ocean world have placed the subcontinent in a wider Asian sphere with its own "connected histories" (Subrahmanyam) and have explained its role in an "inter-imperial" system that endured for centuries (Doyle). ${ }^{2}$

Yet the future of anglophone literary studies remains uncertain because detailed studies of Anglo-Indian literature fit poorly with the larger conceptual frameworks that have surrounded them. ${ }^{3}$ Theories of orientalism and colonial discourse, for all their creative power, have become a roadblock to understanding Asia's anglophone culture, leading either to an "obsessive critique of the West" that only reinforces its singular dominance (Chen 1) or to the pursuit of an original Asia that might ground identities that evade the effects of European intrusion (Spivak 213). Previous scholars dismissed eighteenth- and early-nineteenth-century British Indian culture as negligible or too imitative of European fashions to be unique. ${ }^{4}$ Little is known about Anglo-Indian literary production outside of Bengal during this period and even less about the creation of newspaper verse, the exchange of manuscripts, and other vital but non-elite forms of literary activity. For these reasons, India has become an "abstraction, a reflection, and a projection of British imaginations" (White 2), preventing

(C) 2020 JAMES MULHOLLAND

PMLA 135.2 (2020), published by the Modern Language Association of America 
scholars from ascertaining how Anglo-Indian authors conceived of their publics and defined their artistic institutions.

To recover practices that existed underneath and alongside the metropole, I propose a new literary history of British Asia that would examine its earliest communities in translocal and regional registers. Translocalism refers to intimate, place-based relationships that stretch across regional and national borders, while critical regionalism teaches us to see the region as permeable, not rigidly self-contained, and as a "social convention" that does not necessarily conform to physically contiguous space (Griswold 12). When combined, translocalism and regionalism focus scholars' attention on intersecting networks that facilitate the distribution of people, goods, and ideas in exchanges that exceed immediate proximity (Greiner and Sakdapolark 375; Massey, Power-Geometries 22). Translocal and regional orientations advocate not for eradicating distinctions among places but rather for demonstrating how literary imaginations and geopolitical strategies make those distinctions seem traversable in contextually definite ways.

Ideas about the translocal originated when social scientists in the 1990s returned to insights from previous decades about "local knowledge" to reduce the prominence of the nation and deterritorialization in theories of globalization and transnationalism (Geertz). In response, anthropologists, geographers, and communication scholars developed the concept of translocality, which defined the locale as pervious and extensive rather than insular and restricted. They calculated how movement through space structured social interactions and cultural change. Studies of migration, aid workers, and transnational political resistance accounted for humans in motion (Hannerz), media-generated identities (Appadurai), and "agency-oriented" action in "cross-border spaces" (Smith 7). This initiated an ongoing discussion of translocal- ity as an intermediary between the local and the global (Freitag and Oppen), a strategy for "local-to-local connections" (Kraidy and Murphy 344, 347), a "grounded transnationalism" (Brickell and Datta 7), an assemblage of social movements (McFarlane), and the geopolitics that ensued from that assemblage (Mandaville). All these positions share an interest in concepts that transcend locality through actors or objects that organize themselves across scales (local, regional, national, international [Banerjee]).

Understandably, literary criticism has focused on authorial strategies that developed in response to movement and migration. Jahan Ramazani's "translocal poetics" captures the potential for locality to be "relational" ("Local Poem" 676) when he rejects the idea that poetry must be either "rooted or rootless, local or universal" (Transnational Poetics xiii). Ramazani's translocalism draws from twentieth- and twenty-first-century examples of cultural hybridity and exile, such as those enunciated in African American, Caribbean, and black British poetry by Claude McKay, Linton Kwesi Johnson, Grace Nichols, and many others who were able to dislocate the colonies and "see the metropolis afresh" (Ramazani, Transnational Poetics 165). Daniel Katz suggests that Ramazani's translocalism is a necessary alternative to the "regionalist and universalist narratives" that had previously described these authors (161).

Eighteenth-century Anglo-Indian literature, however, is driven by the peculiar state-dependent yet nonnational sovereignty of the British East India Company (the EIC or "company"). This significant historical difference requires that we combine translocalism with critical regionalism in order to understand literature as an intercessor between porous localities and the clotted global structures created by imperial ventures. ${ }^{6}$ This new sense of translocal regionalism grasps that the transcendence of local boundaries is not only an expression of tactical resistance 
by the oppressed but is sometimes also a constitutive feature of the long-distance cultural relations produced by colonizing modernity. It disaggregates the material flows of people, ideas, and goods in empire while assessing how art makes those flows intelligible.

Without resorting to theories of unitary national identity or a common colonial discourse, translocal approaches to the region explain how Anglo-Indian authors could be situated in specific South Asian environments while retaining associations with Europe. Translocal regionalism resists seeing European empires as composed in a "single analytic field" (Stoler and Cooper 4) and instead supplements the sense that they were a "complex agglomeration of overlapping webs" (Ballantyne 15) by paying new attention to local-to-local interactions that constituted and changed anglophone Asia. More thoroughly mapping the linked locales of AngloIndia's regional culture will result in richer portraits of the relation between writing and empire than those provided by empty abstractions, such as "transnational public," that elide how and where texts get made (Hofmeyr, "Globe" 88) or that establish broad comparisons by assuming empire's constituent parts were simply "variations on the same pattern" (Orsini 348). Translocal regionalism amplifies awareness of how anglophony was influenced by the cultures and languages encountered during Britain's territorial expansion. Anglophony interacted with and benefited from a multilingual India whose traditions were themselves subject to persistent regional influences and variations (Orsini et al. 63).

This essay analyzes three authors who demonstrate the need for translocal and regional approaches in a revised history of early colonial literatures. They had no personal connection, came from dissimilar ethnic and social backgrounds, and were employed in different occupations, but all shared an affiliation with the EIC, which influenced what and where they wrote. The first author I discuss, the pseudonymous Candidus, was a military officer whose translations of Persian love poems (ghazals) reveal how EIC-sponsored language training shaped Anglo-India's multilingual reading publics. The second, Eyles Irwin (1751-1817), was born in Calcutta to an Irish family employed by the EIC. He cultivated a portable literary reputation by coupling his writing to authors and markets in London, India, and China. He believed his associations with and travels through these domains secured a literary position that distinguished him from his contemporaries. $\mathrm{He}$ describes this artistic outlook as a "vagrant muse" who traveled with him across the globe and throughout Asia ("To Mrs. Charlotte Smith"). James Romney (1745-1807), the third author, was a Bombay Army officer born in England whose poems and plays-including a stage adaptation of Laurence Sterne's The Life and Opinions of Tristram Shandy, Gentleman (1761-67)-redefine the contours of Bombay literary culture by reworking models of European sociability. Each author represents distinctive facets of anglophone India's translocal imaginations: Candidus signifies the importance of multilingualism, Irwin the consequences of movement, and Romney the centrality of women's sexuality and manuscript production (not just print publication).

I describe the literary sphere inhabited by these authors by drawing on the artistic and social world of Calcutta, Madras, and Bombay. These were the primary stations of EIC governance, but they are rarely analyzed together by literary scholars. Each of the three authors I discuss was engaged with the specific languages and ethnicities of one of these locations, while also contributing to an embryonic subcontinental culture. Following the links that existed among these places is crucial for reconceptualizing anglophone Asia as a region shot through by the translocal travels of its authors and defined by its partial autonomy from British norms. Anglo-Indian writing was constituted by multisited forces, 
only one of which is the reciprocal exchange between Britain and its colonies that has been the prevailing focus of our literary criticism about empire.

Such a reconceptualization benefits from the insights of social scientists and historians of science, who have dismantled diffusion models of modernity by focusing on the many interacting scales of embedded cultural creation and on the production and circulation of knowledge in colonial spaces (Secord; Raj, Relocating; Harrison). Literary scholars ought to apply to histories of English literature the same attention to cultural change that has appeared in social science's theory of "multiple modernities" (Eisenstadt), which sees this change as proceeding not through diffusion but according to a "logic of selfdifferentiation" that replaces metropolitan norms with new practices from the mixed spaces of India (Kaviraj 504). Taking this approach to English literature necessitates redefining imperial literature as composed of publics that remain outside the orthodox viewpoint that colonizers must either identify with a national homeland, absorbing its fashions and forms, or think of themselves as wild exotics precariously rooted in alien terrain and always seeking to go native.

\section{A Cultural Company-State}

Assessing the translocal and regional scales of writing in eighteenth-century India requires understanding the confluence of two powerful histories: how patronage and finance shaped the production and dissemination of Anglo-Indian literature and how orientalist learning and South Asia's many languages constructed a multilingual anglophony from which that literature emerged. Writing and printing in India exposed issues of administrative control, Miles Ogborn suggests, because both involved the "contested processes of doing imperial politics," especially between 1765, when the Treaty of Allahabad made the
EIC diwan (tax agent) for Bengal, Bihar, and Orissa in northern India, and 1799, when Mysore's Tipu Sultan was defeated by the EIC and its allies at Seringapatam (Srirangapatna), which allowed the company to consolidate control over territory in southern India (201). ${ }^{7}$ Imperial politics necessitated the comprehension of Asian languages, which, though essential to EIC commerce from the beginning, expanded rapidly through companysponsored orientalist scholarship and practical language training that ensured that an India-based print culture would be "hybrid," in the description of Kenneth Hall (89). Hybrid print culture sustained British rule, but it also reinforced regional rather than national identities among India's indigenous populations and its Anglo-Indian communities. Because these linguistic innovations and printing technologies were closely aligned with the trading ventures and resource extractions of the monopolistic EIC-and were supported by its patronage and regulated by its censorship - the company's peculiar status and sovereignty carried considerable weight in Anglo-India's art world. Few corporations have so greatly influenced the development of an entire literary culture, making it akin to a cultural company-state. ${ }^{8}$

Some effects of this cultural companystate have been documented: its support for linguistic study (Franklin, "Hastings Circle”; Marshall, "Warren Hastings"), sponsorship of scholarly groups (Steadman 465, 467), and commissioning of portraits that drew European artists like Johann Zoffany and Robert Home to India (Archer). Warren Hastings, India's first governor-general and a poet, funded Nathaniel Brassey Halhed's A Grammar of the Bengal Language (1778) as a tool for teaching Bengali to company employees (Rocher, Orientalism 76). Ogborn has called this book a "coproduction" by Europeans and natives (243) because while Halhed collected samples of Bengali and Charles Wilkins designed fonts, indigenous religious scholars 
provided the manuscript materials (Qayyum 56-59) that native craftsmen like Panchanan Karmakar, a blacksmith descended from metallurgists and calligraphers, used to craft the book's intricate cursive type (Ross 4-12 [fig. 1]). Afterward, Hastings established a permanent printing office under Wilkins's direction to produce administrative forms in Persian, Bengali, and English (Ross 19) and financed a madrassa in Calcutta to train scholars of Islamic law, or maulvis (Hastings). His successor, Charles Cornwallis, paid "writers"-the EIC's entry-level scribes-a higher salary for learning Persian (Kopf 18n29) and supported the creation of a Sanskrit college in Benares to house a "precious Library of the most ancient and Valuable General Learning and Tradition" (Duncan 78). Calcutta's Fort William College (est. 1800) and Madras's College of Fort St. George (est. 1812) educated EIC employees in Sanskrit, Persian, and vernacular languages (especially Bengali, Telugu, and Tamil) using native texts, such as the $R a$ mayana, an ancient Sanskrit epic, and the Kathopakathan, a series of dialogues about everyday Bengali life, that were printed at college presses (Kopf 69-70, 93) or with the assistance of the Serampore Mission Press, which produced nearly 212,000 items in over forty native languages by 1830 (Dharwadker 111). The EIC subsidized factory libraries like the one at Madras, which possessed 1,235 titles by the 1730s (Shaw, "British Book" 563), and patronized the Asiatick Society of Bengal, which absorbed the three to four thousand manuscripts and books belonging to Tipu Sultan after his 1799 defeat (Lockyer 72, 108)

Expenditures on physical infrastructure-printing presses, language guides, teaching colleges, and libraries-made an Anglo-Indian cultural sphere possible, and language training contributed directly to its literary productions. Classical Persian poets such as Hafez, Ferdowsi, and Sa'di were already a central part of the orientalist canon in the early eighteenth century (Datta 59-60), but knowledge of these authors expanded with the publication of William Jones's $A$ Grammar of the Persian Language (1771), which the EIC recommended to employees, and with proposals for an Oxford University professorship in Persian (Cohn 23; Kopf 18). This kind of knowledge allowed an anonymous "learner of the Persian," a poet identified only as "A.," in 1780 s Calcutta to submit a "lesson of yesterday evening," a translation from Sa'di's thirteenth-century Bustan, a collection of didactic tales, for publication in The Calcutta Gazette; or, Oriental Advertiser, expecting it would meet with approval because it was the "produce of Asia" and acquainted readers with its "diversity of books and authors" (A.). This poet celebrates The Calcutta Gazette for planning "to publish occasionally translations from the Oriental languages, together with the original." Another poet, "Senex," argued that newspaper translations were essential for spreading Persian wisdom lest it be reserved for "the instruction of a few only" who already knew the language. In an editorial, Senex applauds the creators of The India Gazette; or, Calcutta Public Advertiser and hopes his praise will encourage the "many even in the circle of my acquaintance, who employ their leisure hours in Literary pursuits" to submit their poems. These examples suggest that the policies of the cultural company-state actively fostered Anglo-India's translocal and multicultural affiliations.

Corporate support for writing, printing, and language learning created an AngloIndian cultural sphere in which local-to-local orientations and regional nuances were essential. Printed matter was always an important part of EIC servants' possessions, much of it purchased or carried from Britain. Nearly twenty percent of Britain's overseas book exports involved India by the 1770s, and a list of "necessary expense[s]" for new EIC employees included "books of amusement and instruction" worth at least three pounds ("Necessary Expense"), though John Hyde, a justice on the 

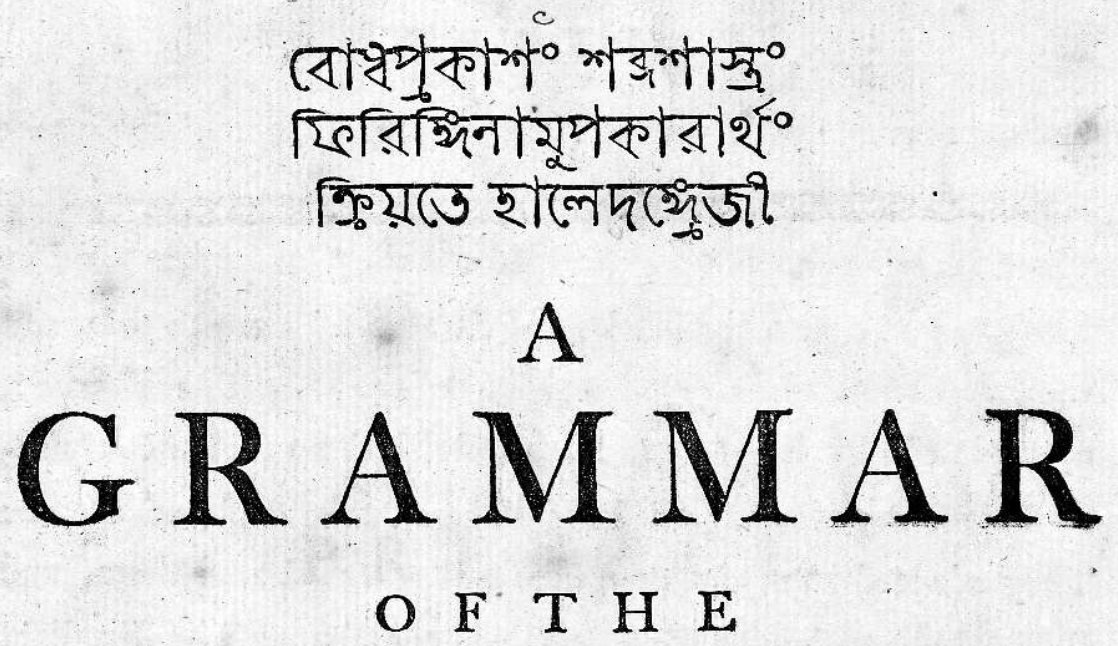

BENGAL LANGUAGE

BY

NATHANIEL BRASSEY HALHED.

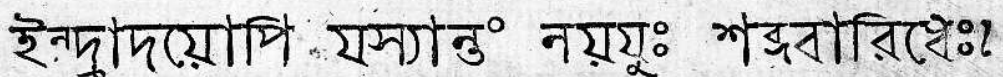

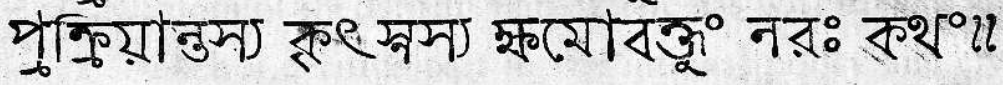

\section{P R I N T E D}

A $T$

HOOGLY IN BENGAL

M:DCC LXXVIII.

FIG. 1

Title page of $\mathrm{Na}$ -

thaniel Brassey Hal-

hed's A Grammar of

the Bengal Language

(1778). By permis-

sion of the Beinecke

Rare Book and

Manuscript Library,

Yale University. 
Supreme Court of Bengal, possessed many more-1,321 titles-by the time he died, in 1797 (Shaw, "British Book” 566). ${ }^{9}$ But it was newspapers, which first appeared in 1780 , that defined pre-1800 India's print world and the local coordinates that structured it. As the anonymous "learner of the Persian" understood, newspapers allowed authors to share their imaginative writing quickly with proximate readers. Opportunities were plentiful because every newspaper dedicated space to literature, such as the recurring poetry sections that were titled "Poet's Corner" (The Calcutta Chronicle) and "The Parnassian Spring" (Madras's The Hircarrah).

Some newspapers were directly sustained by the EIC, which purchased type and allowed distribution through its mail network for free (Barns 68). The Bombay government requested that copies of the Madras Courier be sent regularly and ordered back issues to have a "compleat set" from the paper's first publication (Love 361). The postal system made regional distribution possible: Madras's The Hircarrah, for instance, reprinted an elegy for a British soldier that had appeared weeks earlier in Calcutta's Asiatic Mirror, and Irwin published his "Ode to the Nile," describing his travels through Egypt, in The India Gazette, even though he was never stationed in Calcutta. The continent-wide movement of cultural information resulted in strong local identities best expressed by William Duane, proprietor of a Bengal newspaper called The World, who exulted that "[t]he civilized world affords no similar instance of the rise and culture of the arts, and to such perfection as Calcutta" (qtd. in Shaw, Printing 4).

However, EIC intervention in the cultural state had consequences too, and Duane's enthusiasm for Anglo-India diminished when he was subjected to its regulatory regime. $\mathrm{He}$ advocated for uncensored newspapers, reportedly insisting that "all matters of Public Report and General concerns are discussed in them freely" ("Restrictions" 25), but his confidence disappeared when he was accused of revealing military secrets, imprisoned, and forced to beg for his release (8). He wrote to Bengal's secretary of state, "I am punished, I am humbled, I am sorry" (92). Anglo-India's first newspaper, Hicky's Bengal Gazette (est. 1780 ), was prevented from using the mail system after repeatedly offending EIC administrators, provoking its owner, James Augustus Hicky, to protest by publishing a "Printer's Solilqui," which asks, "To Print-or not to Print-that is the Question" and complains about the restrictions of the "damn'd Post Office" that caused his issues "to die away and loose their Circulation." Surveillance was a potent structuring device for anglophone Asia because, as Robert Darnton notes, repressive censorship is instrumental to an institution's function, not just an external force acting upon it (229-31). The EIC technically controlled who could reside in India, and it thereby regulated the population of writers and printers by deporting those who resisted, like Duane, back to Britain (Little). If, as Natasha Eaton suggests, scholars have undervalued the EIC as a patron of the visual arts (Mimesis 28), they have also underappreciated its significance as both a benefactor of imaginative literature and a censor whose interventions designed literary publics. Paying attention to the EIC's dual role as patron and censor helps to fracture further the sense that British literature operates through a "vast anonymous address" (Hofmeyr et al. 5) by revealing how legal jeopardies specific to the EIC in Asia determined what was written and printed and how it was distributed or how it was suppressed.

\section{Anglo-India's Multilingual Reading Publics}

Although scholars have acknowledged the importance of the EIC for the spread of orientalist scholarship and South Asian printing, more attention to the cultural company-state will produce better understandings of how 
these forces constituted Anglo-India's multilingual reading publics. Multilingualism was central to anglophony's origins (DeWispelare), but it also shaped the regional cultures that grew out of it. In South Asia, anglophony mixed with the subcontinent's massive language diversity to align commercial interests with literary reputation making in ways that characterize the cultural company-state. One mechanism was the reliance of orientalists on collaborators-Hindu intellectuals (pandits), Islamic teachers (maulvis), and scribes (munshis) - to solidify their legal, linguistic, and scientific research. ${ }^{10}$ Less understood is the way the reading and writing of non-elite military officers, merchants, and tax collectors contributed to what Bhavani Raman describes as the "document raj"-an administrative state systematically transforming India into an empire of paper (2). ${ }^{11}$

Even before the document raj, reading and writing were associated with power in South Asia. What Sheldon Pollock calls the "Sanskrit cosmopolis" lasted for a millennium (ending around $1300 \mathrm{CE}$ ["Sanskrit Cosmopolis" 197]) and acculturated Asians into a transregional polity through the shared use of Sanskrit (Language 15), which produced millions of manuscripts on highly perishable palm leaf (Khan 200). Centuries later, the Mughals perceived writing as a tool of trade and diplomacy, its documentary forms securing relationships and delineating hierarchies (Cohn 19), while scribal publication was important for the vibrant dialect mixtures of preprint Bengal (A. Ghosh, "Literary Traditions" 241-42). The Mughal Empire was a multilingual and cross-cultural domain, and its courtly culture, although dominated by Persian in the eighteenth century, had a history that included Sanskrit and other Indian languages (Truschke 2-4). Among the midlevel administrators who were the ossature of the EIC, writing English was a form of collective action (Ogborn 76-79) and language learning was a way to rule (Cohn 21). Both were crucial skills for individuals like Romney, who made notes on military endeavors and likely conversed with his native soldiers in their local tongues, and Irwin, who acted for a time as Madras's revenue collector in Tinevelly (Tirunelveli), where he communicated with assistants like "Sade Tuhivan" (Irwin, Report 99) to bring the area "under the fullest subjection to the Company" (Irwin, Continuation 131). For all these reasons, it is difficult to separate political practices and social life from writing in eighteenth-century India.

EIC support for print intensified the continent's long politicized history of multilingual speaking and writing, a history evident in how reading publics were perpetuated. The first printing presses in India were imported by the Portuguese in 1557 (Rhodes 11-15), but the first press to be used for English was captured by the EIC from the French at Pondicherry (Puducherry) and then relocated to Madras in 1761 with its printer, Charles Delon (Kesavan 62). ${ }^{12}$ In the following decades printing in English spread rapidly: by 1800 there were forty printers in Calcutta and at least seventeen different presses (though only ten at any given time [Shaw, Printing 3]), and more were located in half a dozen other cities across South Asia, printing primarily in English but also in many other languages (Dharwadker 108-09). Type foundries in Calcutta, first established in 1786, produced Bengali, Nasta'liq, and Devanagari type, while foundries in Bombay fashioned Gujarati, Marathi, and Malayalam type, and those in Madras created Tamil and Telugu (Shaw, "From Goa" 13). This infrastructural growth meant that by the 1790s, Persian publications like The Works of Dewan Hafez (1791), edited by the Mughal poet Mirza Abu Talib Khan, coexisted with visually rich newspapers that announced important events, such as Hastings's 1785 resignation, in proclamations in English, Persian, and Bengali ("Proclamation" [fig. 2]). These proclamations indicate the overlapping, but not entirely shared, language 


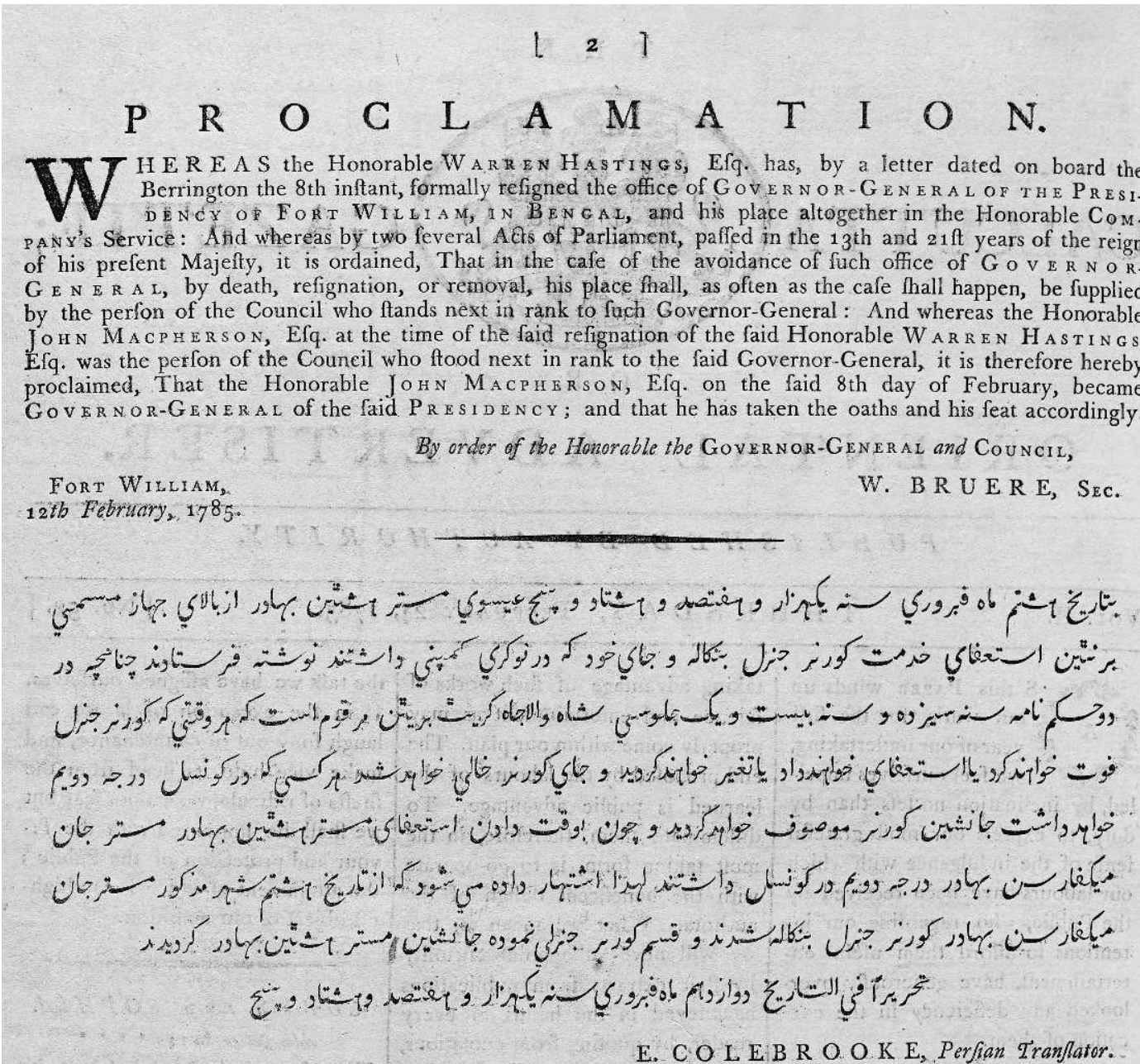

FIG. 2

A proclamation published in The Calcutta Gazette; or, Oriental Advertiser in 1785 announcing the resignation of Warren Hastings as Governor-General of Bengal, printed in English, Persian, and Bengali ("Proclamation"). By permission of the Beinecke

Rare Book and Manuscript Library, Yale University.

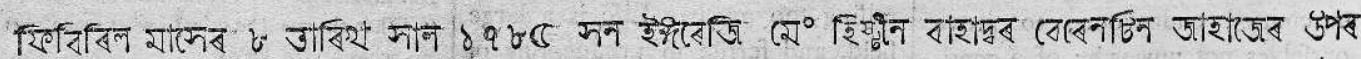

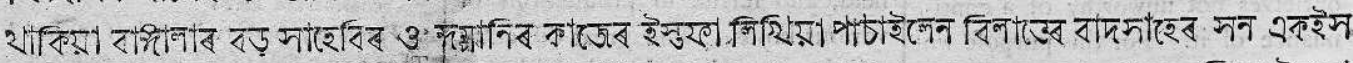

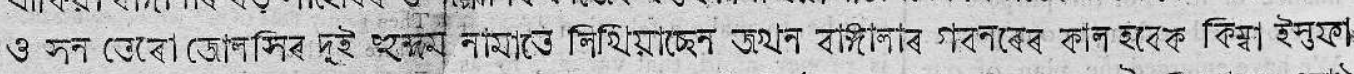

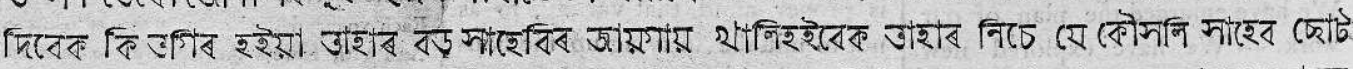

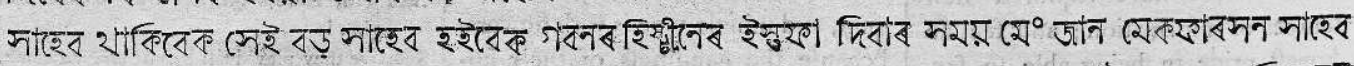

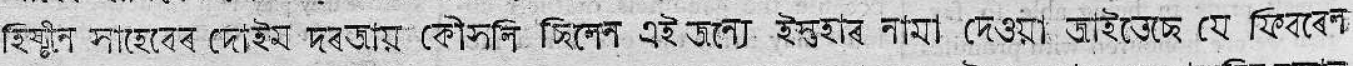

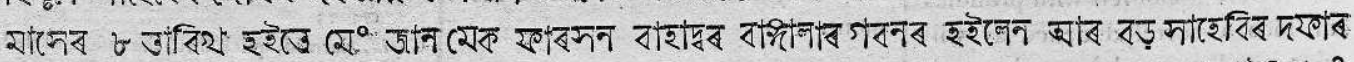

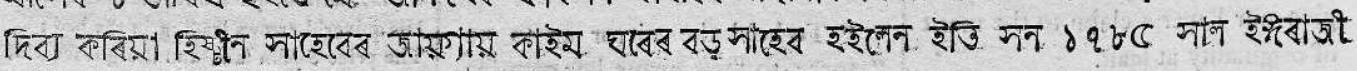
जাবিয । ২ एিব্বেन 
fluencies and reading publics of eighteenthcentury India. Bengali may have been considered lowly and clerical, unlike Persian and Sanskrit, but it appeared frequently alongside those languages in newspapers, presaging its role as what Anindita Ghosh calls the "vital instrument" of nineteenth-century Indian national identity (Power 45, 3-4). And though Sanskrit and Persian were the focus of eighteenth-century orientalists, Tamil was India's first printed language (Blackburn 31). Sixteenth- and seventeenth-century Portuguese experiments in printing Tamil, in Goa and Lisbon, were later taken up by Danish and British missionaries in southern India (Blackburn 58-59) so that by 1800 there were already 266 Tamil titles in print (Shaw, South Asia and Burma Retrospective Bibliography 13), among them a Tamil-English edition of John Bunyan's The Pilgrim's Progress (1793), the first novel printed in South Asia (Joshi 38 [fig. 3]). Published outside of Madras in Vepery by the Society for Promoting Christian Knowledge, it followed several editions of the Bible (from 1715, 1766, and 1772) and dozens of interlingual grammars and dictionaries (Blackburn 51, 58-59). The edition's separation of languages into columns suggests a desire that readers compare the two versions. That Bunyan's novel contained a complete intellectual world explains its appeal to global audiences and its effectiveness as a method of conversion (Hofmeyr, Portable Bunyan 2), but its Tamil translation also signals how missionaries sought to establish trust with South Asia's different ethnicities and religions by routing Anglo-India's multilingual reading publics through English literary works (Blackburn 29).

If printed artifacts are a "metonym for an abstract public," as Michael Warner suggests (62), then the form of those artifacts captures the imaginative qualities of that public but also the nonabstract forces that organized it. The familiar twin-column layout of the Vepery Pilgrim's Progress that placed Tamil and
English side by side was particularly prevalent in newspapers and suggests that cultural relationships were driven by comparison and appropriation, not just the desire for converts. Consider "I told my friend, in artless lay," the translation of a Persian ode by Candidus, a regular contributor to the Madras Courier. His translation reworks a ghazal by a thirteenth-century poet and courtier of the Delhi Sultanate, Amir Khusrau (Gabbay 36), which sets Persian alongside English in a 1790 issue of the newspaper (figs. 4 and 5). A ghazal is a love lyric that originated in seventhcentury Arabic before migrating into Persian as it moved through central Asia to India (de Bruijn). It involved song making, ambiguous genders, and complex quasi-religious philosophizing and mysticism, and Khusrau was its most important popularizer in India (S. Sharma 42-43). ${ }^{13}$ Its elegant Persian cursive was, like Tamil or Bengali, difficult to make into type, and "I told my friend" indicates how quickly technologies for multilingual print had advanced since Halhed's 1778 Grammar. The poem's geometry proposes multiple ways of reading: one could begin, for instance, along its slim central spine of white space and move outward toward the margins, comparing Persian and English (since the languages read in opposite directions), or scan back and forth between lines to assess the translation's qualities.

Little is known about the pseudonymous Candidus, who was identified in another poem printed by the Madras Courier as an officer with the "Grand Army of India" during the third Anglo-Mysore War ("Verses"). An author using the same pseudonym published multiple poems in The Calcutta Gazette in 1784, including an imitation of Horace ("An Ode on the Introduction of the Cold Weather"), an English ode rewritten from Anacreon ("An Ode: Translated from Anacreon"), and a ghazal translation of "Amir Khoseru” ("A Song of Amir Khoseru”). The vast majority of Anglo-Indian newspaper 


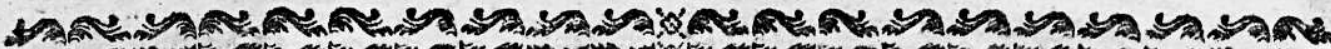
A

\section{$x$ н $\mathrm{B}$}

$$
\text { Pilgrims Progrefs: }
$$

(S I M I I I T U D E O 82

D R E A M.

A S I walked through the wilA derneis of this world, I lighted on a certain place, where was a den and laid me down in that place to fleep : and as I flept, I dream. ed a dream. I dieamed, and behold, "I faw a man clothed with " rags, ftanding in a certain place, I6 with his face from his own houfe, "s a book in his hand, and a great " burden upon his back." I looked, and f.w him open the book, and read therein; and as he read he wept, and trembled and not being able longer to contiin he brake out with a lamentable cry, faying, Wbat baill I do?

In this plight therefore he went home, and refrained hinifelf as long as he could, that his wife and children thould nut perceive his diftrefs ; but he could not be filent long, becaufe that his tiouble increafed: whirefore at length he brake his mind to his wife and children; and thus he began to talk to them?" " my dear wite, faid he, and you the at myildren of my bowels, I your ad dar friend, am in myfelf wridone, ic by reafon of a burden that lieth "i hird upon me: moreover, I am o certainly informed, that this our of city will be burned with fire ic trom heaven : in which fearful "s overthrow, both myfelf, with " thee my wife, and you my fweet ef babes, thall miferably come to i. ruin, except ( the which yet I (6 fee not) fome way of efcape may of be found, whereby we may be is delivered ."

FIG. 3 At this his relations were fore amazed; not for that they believed that what he had faid to them was true, but becaufe they thought fome frenzy diftemper had got into his lead therefore it drawing towards night, and they hoping that neep night fettle his brains, with all hafte bigy got him to bed : but the night was as troub!efome to him as the day; wherefore, infead of neeping he lpent it in fighs and tears. So whis

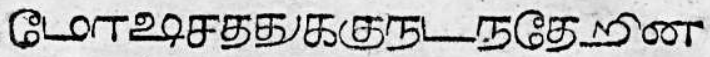

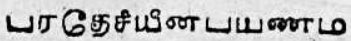

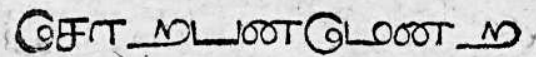

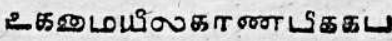

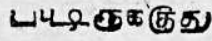

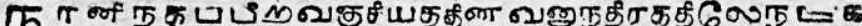

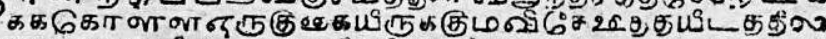
வந5

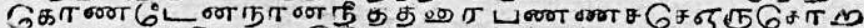

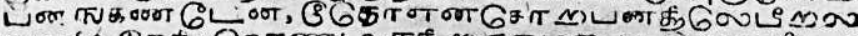

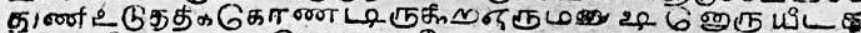
\$6 6 நु

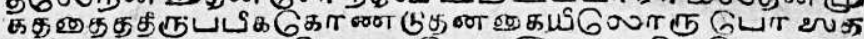

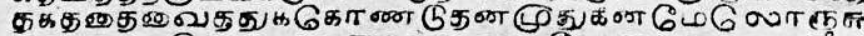

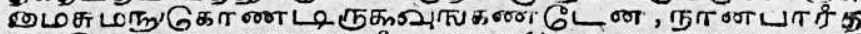

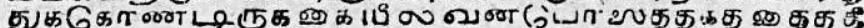
ज्ञा5

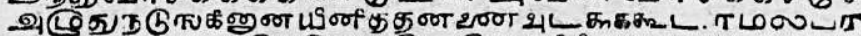

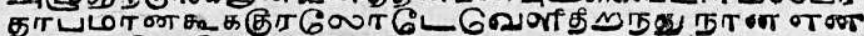

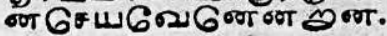

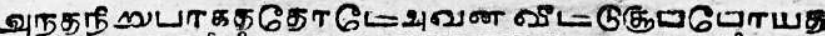
Б001 Сu

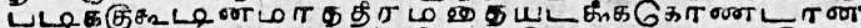

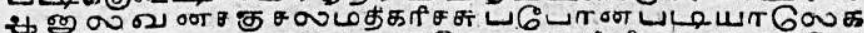

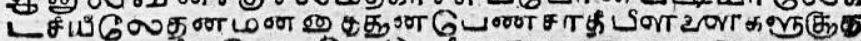

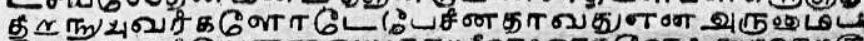
6U 6

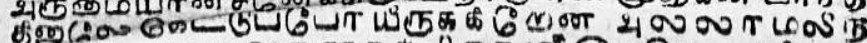
की LUL

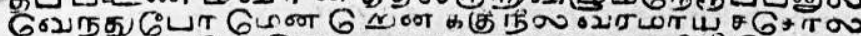

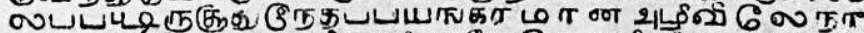

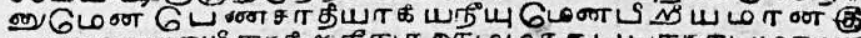

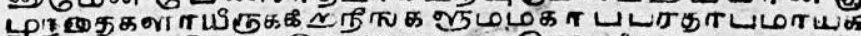

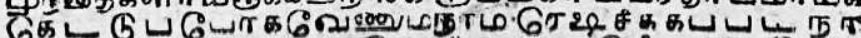

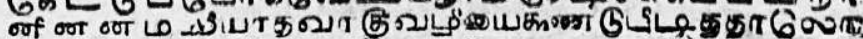

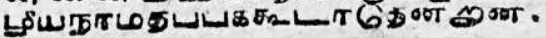

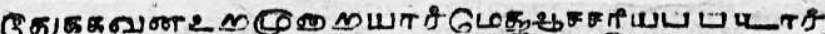

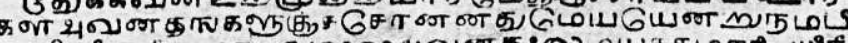

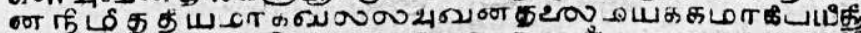

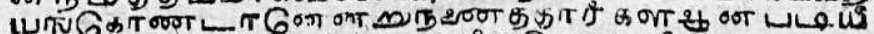

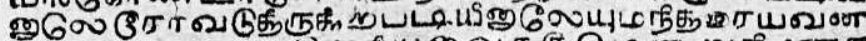

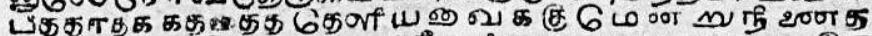
की

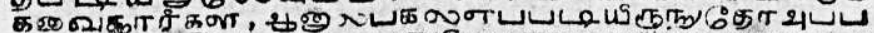

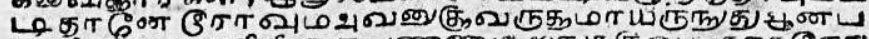

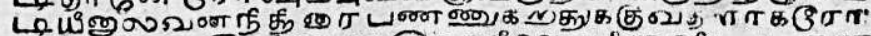

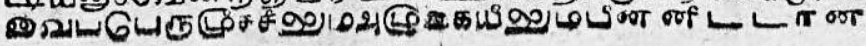




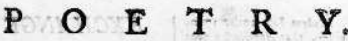

TO THE EDITORS OF THE MADRAS COURIER.

D ERMIT me, Gentlemen, to fend you a very pretty Perfian Ode $\mathrm{P}$ by Ameer $\mathrm{Kb}$ : fro, the favourite Poet of Hindollan, with a litera tua.ilation untu Englifh Verfe of the fame numben nearly as the Original.

$$
2 \text { TRANSLATION. }
$$

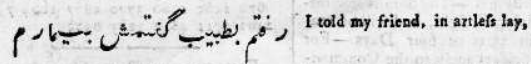

fl I could not Aeep from night till day,

$$
=m_{b}, \quad \text { And afked his ailful aid: }
$$

- He felt my pulle, and friling faid,

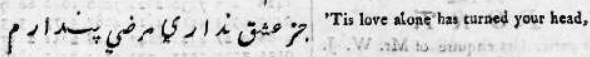

$$
=0 \text { Pray who's the lovely maid? }
$$

Gotell her frait, hove mach you love! . How much you grievel if the approve, - Her lips will life impart,

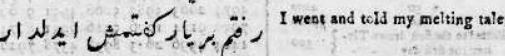

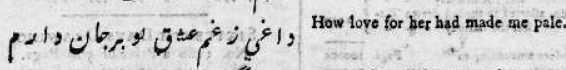
An And preffed upon my heart.

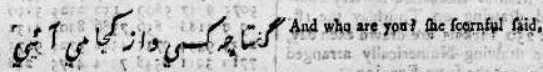

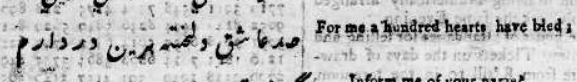
تmequ

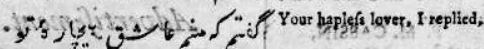

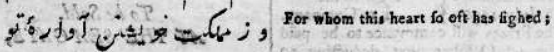

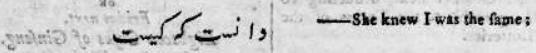

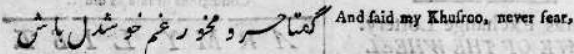

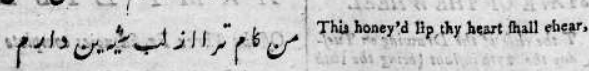

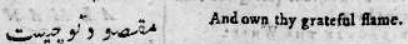

Wand tw a candidus.

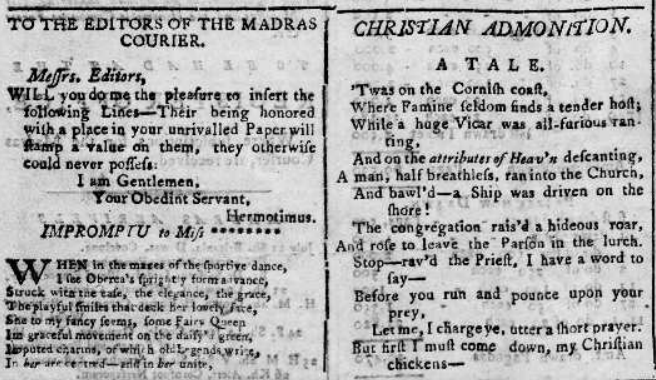

$M A D R A S$.

\section{PR I C E CURRENT.}

15. NOW mof accaratidy given from tho AC COUNTS, of THA PALACLPAL MER. снАИ SA.

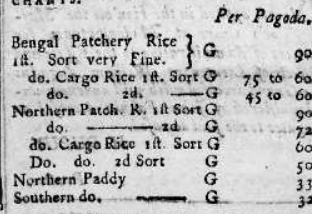

90.

\section{$B$}

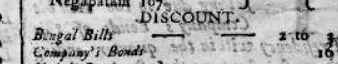

Cavary Bands 1 - 35

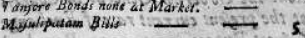

\section{as y s FOHT St. GEORGE, Printed by CHARLES FORD, at the Regifter Office,}

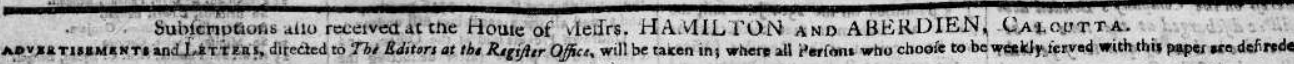
THE EDITORs requeft the Subfcribers to the Courier will gave them notice when thay are about to change their refidence that no miftake be made in the Direftion.

FIG. 4

A page from the $\mathrm{Ma}$ dras Courier (28 July 1790) displaying Candidus's translation of a Persian ode, "I told my friend, in artless lay," with the original Persian to the left of the English translation. By permission of the British Library, Asia, Pacific \& Africa SM 126. 


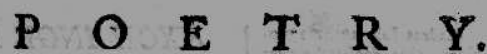

\section{TO THE EDITORS OF THE MADRAS COURIER.}

DERMIT me, Gentlemen, to fend you a very pretty Perfian Ode 1 by Ameer Kb:fro, the favourite Poet of Hindoftan, with a literal tranflation into Englifh Verfe of the fame number nearly as the Original.

$$
2 \text { TRANSLATION. }
$$

p 1 م- 1 told my friend, in arlefs lay,

P ا

$$
=j_{b}, \quad \text { And afked his otilful aide }
$$

(iطن He felt my pulfe, and fmiling faid,

$$
\text { Pray who's the lovely maid? }
$$

Gotell her frait, how much you love! ب.. How much you grieve! if the approve,

$$
\text { زبـ jer lips will life impart, }
$$

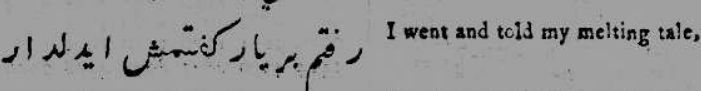

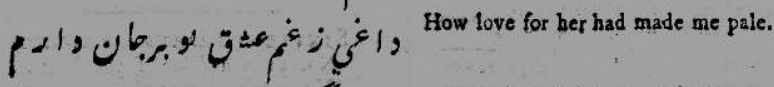

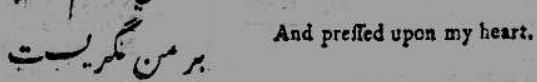

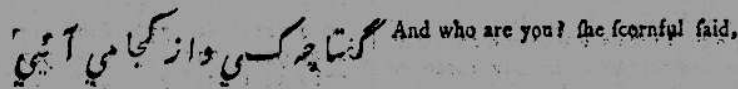

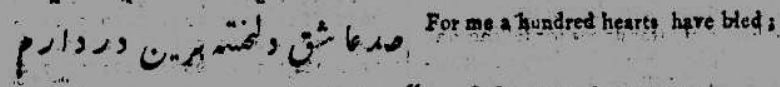

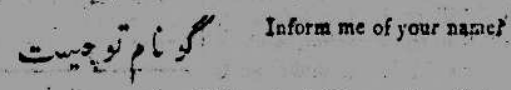

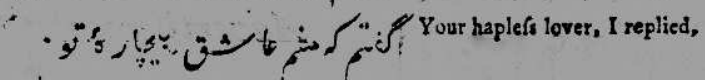

i's

$$
\text { - She knew I was the fane; }
$$

FIG. 5

A close-up of Candidus's poem

"I told my friend, in artless lay."

$$
\begin{aligned}
& \text { This honey'd lip thy heart thall ehear, } \\
& \text { CAnd own thy gratefal flame. } \\
& \text { CANDIDUS. }
\end{aligned}
$$


verse was published under pseudonyms, so we cannot be sure that the Candidus of the Madras Courier is the same person as the Candidus of The Calcutta Gazette, but the poems under his name strongly suggest a mobile individual or someone who could publish across British India.

A bit more can be ascertained about who might have read "I told my friend," because the content and visual presentation of Candidus's translation reveal what propelled Anglo-India's reading publics. The poem's layout suggests the sophistication and variety of the audiences it pursued. Although the English translation dispenses with the repeated end-stopped lines (radif) and internal rhymes (qafia) of the ghazal (Kanda 1-2), it maintains its couplets and mentions Khusrau's name in the last stanza, a technique called takhallus in which an author includes a name that serves as a "signature" and as "evidence of authorship" (Losensky 245). Paul Losensky believes this type of turn is a sign of subservience to the beloved who is extolled by the poem, but in the case of Candidus's translation it also identifies an author from a preceding literary tradition (248). As the translation ends, Candidus writes, "[S]aid my Khusroo, never fear, / This honey'd lip, thy heart shall chear, / And own thy grateful theme." Retaining this sign-off while disregarding other techniques implies that Candidus sought to transmute the traditional subject matter of ghazal-the affection between lover and beloved-into affiliations between Anglo-Indian versifiers and the Persian lyric. Most of the poem is a speaker's "artless lay" addressed to the person he loves, but it also expresses Candidus's relation to Khusrau and Persian poetry. The obvious intermediations of the poem, such as its translations from one language into another printed beside it, stand as well for connections that transcend differences in culture, place, and time. But the poem is also an intervention into a competitive multilingual literary sphere in which EIC employees broadcast their skill by associating themselves with artistic predecessors and publishing poetic imitations of them. With "I told my friend," Candidus makes clear to other writers like Senex and the "learner of the Persian" that he too knows the classical canon.

That close relation between English versifiers and Persian poetry reformulates an appropriation of traditions as a literary affiliation across time. Candidus's translation displays visually, even ostentatiously, the generative potential of Anglo-Indian literature to draw on other cultures and adopt the authority of the Persian lyric's long history in South Asia. Because ghazals had spread to Asia from Arabia, Robert Fraser describes them as a "transregional" genre (62), while Thomas Bauer and Angelika Neuwirth argue that they "compare cultures" (22). Cultural comparison is built into the form of Candidus's ode, as I noted, but it also binds Persian transregionalism and British economic globalism together by locating and aestheticizing India's politics, which prized knowledge of Persian because it was the language of Mughal Empire officials. In fact, "I told my friend," and the many translations like it, show that while AngloIndian newspapers were modeled on European predecessors, the prevailing argument that there was a "dearth of local news" so that "British newspapers were shamelessly cannibalized for column inches" by proprietors in India is wrong (Shaw, "India" 457), as is the notion that newspapers were national institutions that primarily built national identities (B. Anderson; Potter 12-13). In eighteenthcentury South Asia, newspapers were an essential venue for multilingual reading publics conversant in techniques of appropriation and cultural comparison supported by the company-state. Non-English traditions provided opportunities for authors to innovate within appropriated forms and to appeal to the new literary publics of educated readers aware of the voluminous linguistic legacies around them. Newspaper authors like 
Candidus "reach into and manipulate" the "indigenous systems of communication" that C. A. Bayly calls the colonial information order (Empire 6) with the goal of constructing a translocal poetics that reflects their circumstances. That their aesthetic forms legitimized appropriation only intensifies the need to acknowledge such overlooked contributors to eighteenth-century orientalism.

\section{Translocal Poetics and the Making of a Portable Literary Reputation}

While Candidus secured his reputation by associating with classical Persian, Irwin sustained his literary career by establishing physical and imaginative ties throughout Asia and back to Hellenic history. Born in Calcutta in 1751 and educated in England, Irwin was posted in 1766 to Madras. He acted as a clerk, revenue collector, and surveyor in the EIC's Fort St. George Presidency, ultimately leaving the company in 1794 after traveling to China in an advance party for George McCartney's first-ever British embassy to the Qing Empire (Prior; "Memoirs" 179; Hevia 57, 82). With Madras as his central mooring, he was involved for most of his career in literary publics that extended from London to Macau, at the same time affiliating with authors and artists current and long past. He fostered a portable literary reputation that transformed his travels through Asia and back to Britain into an expression of his uniqueness and poetic novelty. His career indicates the difficulties of being an author who appealed to audiences in England while promoting more proximate ones in India. $\mathrm{He}$ exemplifies a class of late-eighteenth-century India-based authors who should be understood in translocal and regional frames.

If Irwin is known at all, it is as an author performing Indian identities for audiences in England. His second published poem, Bedukah; or, The Self-Devoted (1776), represents the dying cries of a sati, who by immolat- ing herself resists imperial power (Teltscher 220-21) and articulates an alternative to the poem's spectating colonizer (Schürer 34-36). "Ramah; or, The Bramin" (1780) similarly conveys the speech of someone committing suicide in an act of defiance: in it, an Indian holy man, with "rage possest" (line 25), delivers a lengthy rebuke of British colonial policy and Mughal oppression of Hindus before throwing himself to his death from the top of a temple in Conjeveram (Kanchipuram) as "a lesson to the British throne" (line 120). Irwin, especially in the early part of his career, was a frequent impersonator of native Indian characters expostulating on the dangers that the British Empire created with its conduct.

In addition to this poetry of empire, however, Irwin placed himself in relationships that were unapologetically local yet elastic. His first published poem, Saint Thomas's Mount (1774), maintains that southern India is more nurturing for writers than England, and it uses pastoral, georgic, and topographical modes to explain how Asia might revitalize English-language poetry. He persuaded his London publisher, Dodsley, to send "out an edition of [his] works to the several Presidencies" (of Calcutta, Madras, and Bombay), certain "that curiosity and knowledge of me would get them off" (i.e., get them sold [To William Hayley]). ${ }^{14}$ Irwin understood that his status as an EIC merchant and the topics of his writing would make him familiar and appealing to Anglo-Indian audiences, not just to the exoticism-seeking readers in England who Dodsley assumed were the more obvious purchasers of Irwin's writing.

In one of his last published poems from Asia, "To Mrs. Charlotte Smith, on Her Various Works" (1794), Irwin allies himself with this innovator of British poetry to describe his distinctive Eurasian "vagrant muse." Written in 1793 in Canton, China, Irwin's laudatory sonnet seeks to transfer Smith's fame to himself. He portrays Smith, who renewed interest in the sonnet with her Elegiac Sonnets 
(1784 [Knowles 46]), as a "Creative mind!" whose poems were "treasures to the dazzled day" (“To Mrs. Charlotte Smith”). Yet Irwin's appreciation really is an account of his translocal poetics, which he argues emerges from "Tygris' banks" (Mesopotamia), "Afric's headlands" (the Nile), and "Petrea's steril way" (the Arabian desert), each of which had "woke Cathay" (China ["To Mrs. Charlotte Smith"]). All of these were places Irwin had traveled through as an EIC emissary. He portrays himself as having brought poetry to each place, or having restored its voice when it had gone silent, making "To Mrs. Charlotte Smith" an account of his culture-giving artistic gifts. With his personal geography, Irwin maps anglophone poetry's power to knit together seemingly disparate locales. He distinguishes himself from Smith's "track" to literary fame by arguing for an alternative mode of inspiration, one that evolves from Eurasia rather than from the roots, rocks, and rivers of Smith's England.

Irwin imagined these places as audiences for, not just influences on, his poetry-as publics that grew along the "steril way" of his travel ("To Mrs. Charlotte Smith"). One of the most significant was Madras, and its literary culture is the subject of his "Prologue, Written for the Opening of the Lyceum at Madras 1782." Though never published, it was read aloud at the Lyceum's inauguration and provides a window into Madras as it instituted a literary culture in the early 1780 s. Little historical information exists about the Madras Lyceum beyond Irwin's poem, in which it is represented as surrounded by enemies, particularly Haidar Ali, father of Tipu Sultan, and his Kingdom of Mysore to the west.

Like his poem to Smith, Irwin's "Prologue" portrays his public as sustained by art's ability to amalgamate translocal and transhistorical affiliations. Instead of accentuating the geographically proximate multilingual readers targeted by Candidus or the interlingual exchanges and translated texts that spurred the Vepery Pilgrim's Progress, Irwin looks toward the Mediterranean past for models of Madras's anglophone world. He describes the Lyceum's audience as akin to "Thermopylae's devoted band," reconceiving Anglo-Indians as the Greeks who sacrificed themselves in $480 \mathrm{BCE}$ to oppose the invading armies of Xerxes. But unlike the ancient Greeks, Madras's Anglo-Indians can be saved by listening to poems. In response to the question "Amid this strife on what shall wit rely / Where taste resort, or Sentiment apply?", Irwin offers the Lyceum and his poem that sanctifies it, both of which allow "some bolder minds their views [to] proclaim / to blow the dying ember into flame / With wit's remains to make our glorious stand / And from unleashed darkness, shield the land." Irwin's depiction of Anglo-Indian audiences as soldiers who stand against "unleashed darkness" is culturally dismissive and reflects the violent militarism essential to their economic survival (Ahmed). Yet in overlaying the geography of Thermopylae with that of Madras, Irwin associates his immediate audience with the "bolder minds" that seek with their "views" to "blow the dying ember into flame" and thus "shield the land" ("Prologue"). In the process, he makes hearing his poem a matter of life and death. Through the mechanism of the poem, the Lyceum becomes the place where multiple forces converge in the nascent public sphere of Madras to save Asia's anglophone poetry in its infancy by encouraging others to "proclaim" their views.

As celebrations of the "vagrant muse" and the Madras Lyceum indicate, Irwin's translocal poetics resembles what historians of science have termed "moving localities," in which specific places are not "coincident or constrained by location" but in fact rove beyond it as a "complex set of connections, allegiances, and commitments" that stretch the boundaries of what is proximate in space and time (Raposo et al. 167). Irwin's translocalism likewise is a cluster of formal 
innovations and cultural positions organized around geographic locales, written about and remembered, motivated by the movements of his career, but portable, not entrenched in those places as residue. Translocalism is constituted in contradiction: Irwin is inspired by these locales but also revives them from sterility; anglophone poetry is life-giving and yet rejuvenated by the places that Irwin has visited. What James Clifford has identified as culture's bifocal attention to routes and roots (3) appears in Irwin's writing as a way to define literary success in Asia as a set of authorial connections (Charlotte Smith), historical commitments (ancient Greece), and assertions of mobile localities whose relation to him is guaranteed by, and generative of, their author's reputation.

\section{Rewriting Tristram Shandy in Bombay}

One way to recognize the contributions of authors like Candidus and Irwin is to explain how their translocalism aligned with the better-known orientalism of imperial print culture, as I have done. In this model, technological shifts toward print altered South Asia in favor of British colonialism and eventually solidified the identities of colonizing and colonized peoples. Yet the close association of orientalism with print has had the unintended consequence of concealing the importance of manuscripts for anglophone India's less-studied literary settings and sociabilities. The obscurity of manuscript literature, as compared with the visibility of the EIC's vast handwritten commercial and political archives, has turned scholars toward Bengal and away from other locations such as Madras and Bombay, because Calcutta developed the most robust print culture before 1800 .

The career of James Romney demonstrates the need for histories that value these other literary settings and their manuscript productions. His writing offers a glimpse into Bombay that undercuts the influential claim by Percival Spear that the city's "parochialism" made its one thousand European inhabitants "ashamed" (66). ${ }^{15}$ Romney rewrites "conversational" (Mee 4-12) and "spectatorial" (Dwyer) models of normative European sociability, with its politeness, gendered social interaction, and abundant marital, financial, and personal intrigues, to advocate for Bombay's vibrancy. Like Candidus and Irwin, he bends the institutional logic of imperial governance to fit local and urban sociabilities.

Born in England in 1745, Romney is rarely recalled now except as the younger brother of the portraitist George Romney (and a distant cousin of the 2012 United States presidential candidate Mitt Romney). ${ }^{16}$ As an officer among Bombay's native infantry from 1777 to 1803 , he was a prolific poet, playwright, and letter writer. He never published in Europe, instead spreading his work across Bombay's art world through manuscript coteries and printed newspapers. He submitted regularly to the "Poetry Corner" of the Bombay Gazette (one of the city's earliest newspapers); in letters to its editors he assured them he was no artistic "novice" "To the Editor" 15r) while also warning them not to publish local competitors whose poems "convey no meaning" ("Mr. Editor" 11v). Occasionally his poetry, which mostly remained in manuscript, derives its startlingly innovative syntax from the language of Hindu traditions. In a poem about inspiration, for instance, the speaker implores:

You who from Brama claim your high descent To whom the Bramen Gods have wisdom lent By you my Muse By you My Muse is big. ...

(“Sager!” 76r)

It is not clear to whom this poem is addressed, but it refers to the gymnosophists, a Greek tradition that was syncretized with medieval European portrayals of India's Brahmins as naked ascetics (Juncu 87; Hilton 206). With its form, the poem implies written experi- 
ments with the incantatory aspects of Hinduism-perhaps through devotionals in Tamil, a language Romney may have read and spoken, that are akin to Jones's better-known Vedic imitations from the $1780 \mathrm{~s} .{ }^{17}$ Like Candidus's expansive generic scope and Irwin's inspirational vagrancy, Romney's "big" "Muse" collected translocal and transhistorical influences, broadening the range of his writing while also infusing it with details specific to India. He composed theatrical comedies on "oriental manners" and dramatic adaptations of European literary fashions, such as when he reworked Sterne's sentimental novel, Tristram Shandy, for the stage. His is among the earliest anglophone literary careers of Bombay, and he offers unusually detailed insights into the contours of its culture.

Among the valuable items of his archive are letters to "Mrs. Town," the "Patroness of Public Amusements."18 Mrs. Town is never identified in the letters, though contextual details suggest she may have been based on a prominent female figure. Romney's letters, signed in his manuscript under the name "Unanimity" (e.g., "To Mrs. Town" 4r), outline reforms to Bombay society that would facilitate communication between the (white) men and women who make up what he calls Town's "metropolitical empire" (1r). His use of this phrase to describe Bombay's social scene suggests that the "metropolitan" is made in India, not Britain, and that Bombay might act as its own social "empire."19

In the Mrs. Town letters, he proposes a citywide "Board of Controul," adopted from London and reminiscent of the Parliamentappointed Board of Control that oversaw the operations of the EIC after the passage of the 1784 India Act. He pairs this board with an "assembly" consisting of the "wives of men of fortune, citizens, Lawyers \&c." ("To Mrs. Town" 3r), making women associating together a potent political force in Bombay at a time when their participation in British politics was seen as detrimental to it (Wil- son 203). Together, this board and assembly would regulate Bombay's community. Romney's proposal modifies the city's sociability by organizing it according to principles borrowed from the governing structure of the EIC but also by introducing essential responsibilities for women.

As with his poetry and letters, Romney's dozen handwritten plays overturn the idea that colonial India was simply a reproduction of British society. These plays, in different states of completion, are pitched to AngloIndian audiences: some were performed for groups of friends while others include lavish stage directions that hint at larger theatrical aspirations. There was one area playhouse, the Bombay Theater, which opened in 1770 or 1776, and while no evidence exists that it staged his works, in a letter from 1802 Romney worries that one of his plays was stolen by the "numerous writers of dramas" in India seeking to "adapt and finish it with necessary alterations for the stage" and pass it off as their own ("My Dear Sir" 24r). ${ }^{20}$ His concerns indicate fluid intercourse between intimate groups of readers and the more public artistic infrastructure of theatrical Bombay and hint that demand for Anglo-Indian dramas among its community was high enough to inspire plagiarism or theft.

Women had maintained an important role in British theater for nearly a century by the time Romney was writing their roles in India (M. Anderson; Freeman; Lowenthal; Rosenthal), but his depictions alter our sense of the gendered "imperial social formations" that Mrinalini Sinha argues consolidated a white British self overseas (504). At the center of his play on "oriental traits" (called variously The Pavilion: A Comedy in Five Acts and Oriental Traits), is an extended flirtation between the young EIC wife Belinda Amaranth (Pavilion 2r), whose husband has left Bombay to enrich himself at the Maratha Confederacy's capital, Pune (3r), and Colonel Amourville, who was an army officer and 
"poor as a rat" $(18 \mathrm{v}){ }^{21}$ The play follows Amaranth and Amourville's frustrated attempts to meet privately while pursued by Bombay's "inquisitive and ill-natured" society (25r).

A fixture of that inquisitive community is the play's humorously judgmental elderly couple, the Oldstanders, whose decision to remain in India for twenty-five years becomes a critique of British life. At one point Mrs. Oldstander strikingly declares her close association with regional identity by imagining herself as a sati. After her husband jokes that she should "go to England" if she wants a cool breeze, she retorts that she would rather "go to the devil," insisting that she'll "turn Braminy first, and stay in India to be burnt alive with you my dear" (3v). In addition to proposing the remarkable idea that a white woman might convert to Hinduism ("turn Braminy") and identify with its "good wife" (A. Sharma et al. 77), Mrs. Oldstander's remarks vehemently reject England as worse than going "to the devil." At the same time that Samuel Foote's play The Nabob, first performed in London in 1772, solidified the literary depiction of the EIC's rich indulgent employees returning to Britain and corrupting its values, the characters of Romney's plays dispel that depiction, rupturing the image of AngloIndians as homesick nabobs. ${ }^{22}$ Figures like the Oldstanders might be perceived as buffoonish geriatrics and self-satisfied colonizers, but they also embody an affirmation of the lifestyle of longtime residents in India, as their surname suggests. Their exclamations demonstrate explicitly that England was no longer the "normative starting point" of their identity (Nechtman 24). They may belong to the last generation for whom this is true: as India became more populated with Europeans beginning in the nineteenth century, it may have become less, not more, autonomous from European social models.

Perhaps the most ambitious redefinition of Anglo-India's regional sociability and artistic culture appears in Romney's theatrical adaptation of Tristram Shandy within the localized imperialism of Mrs. Town's Bombay. Romney's “Tristram Shandy" uses many of the same characters as Sterne's novel (Romney, "Pages"), but it removes notable features like the unwound clock, the window sash, and accounts of Tristram's birth that required him

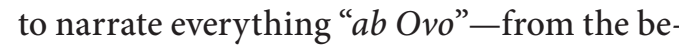
ginning (Sterne 8). In the place of Sterne's formal innovation is a startling plot revision that reimagines the relationship between Tristram and Widow Wadman, who in Sterne's novel is fascinated with Tristram's Uncle Toby, as a sexual attraction explained through the language of empire. Tristram claims that he is searching for the "empress" of his heart, to which Wadman replies by volunteering that if she were "a princess and in the list for such an empire" she would "try with all my heart to be at least as near the throne as my sister candidates" (Romney, "Pages" 23r). She views Tristram as love's emperor-perhaps its Mughal emperor-and Toby merely as a "sober sedate gentleman" (14r). Addressing the theater audience, she admits that she is "always thinking" of Tristram and that "[i]f Mr. Tristram ... should make [an] offer" of marriage her "heart would be in danger" (20r).

By the play's end, Toby and Wadman are predictably reunited, but not before she is jilted by Tristram for Delia Longjaw, the daughter of a justice of the peace, which leaves her cursing her "silly heart" (85r) and vowing "vengeance" (85v) on Tristram, while he grumbles about the misunderstandings that arise from treating women with "too much kindness!" (84r). Delia sees her own matrimonial chances in imperial terms too: after she is promised to a decrepit family friend, rather than Tristram, she pleads instead to be sent into the "fishing fleet" of eligible women in India, remarking, "Let me marry any thing, send me an adventurer to Bengal" (80r). Her father, seeming to direct an innuendo at his knowing Anglo-Indian spectators, jokes that India "will neither 
mend your morals nor procure you a better husband" (80r). This play imagines an audience of Anglo-Indians laughing at their English cousins rather than imitating them.

These references to love, money, and imperial matrimony are part of a larger pattern by which Anglo-India supplies the backdrop against which sociability can be reimagined as governed by women. At the same time, the play depicts a sexual system that endorses women's active desires. Felicity Nussbaum associates eighteenth-century India with the potential for "unorthodox femininity" (176), and Michael J. Franklin claims India was a "transgressive space" for Anglo women (Introduction xxxi). Their descriptions are underpinned by the relative scarcity (and thus high value) of marriageable European women, but Romney's play suggests another possibility. Typically, adaptations of Sterne's fictions are dismissed as "Sterneana," less original than their prototype. In the place of Sterne's narrative and graphic innovations, however, Romney's “Tristram Shandy" promotes Anglo-Indian women's social power and assertive desires, as found in Mrs. Town and then reflected by Wadman's and Delia's sexual vocabulary of empire ("Pages"). If, as Thomas Keymer suggests, Sterne was the most fashionable mid-eighteenth-century author, then Romney aspires to amalgamate that fashionability with Anglo-India's "oriental traits," rewriting Wadman and Delia as versions of Bombay's "metropolitical empire," which he distributes through his stage adaptations and manuscript compositions (3). Romney's plays reposition Sterne's literary experiments within a colonial theatrical world whose characters, like Mrs. Oldstander, would sooner "turn Braminy" than exchange India for England. Scholars might miss such innovations if we isolate individual authors' inspirations instead of examining them translocally, or if we demand that the representation of social change correspond with more obviously unusual generic forms and graphic idiosyncrasies, like those of Sterne's novels.

\section{Forgotten Authors and the Translocal in Literary History}

Historically, the disciplinary category "British literature" has included regional constituencies that scholars have assumed are strongly related to Britain, and to one another, because of their shared linguistic patrimony and the expectation that since they were white they must have an affinity for Europe. Combining the techniques of translocalism with new understandings of the region and of colonial modernity can guide scholars toward other archives of writing that alter the history of British literature. For authors like Candidus, Irwin, and Romney, the regional is not the antithesis of European Enlightenment's universal ideals, but neither is it an endorsement of narrower "local color." They adapt common English literary traditions to India's resident customs in ways that seem to define provincial aesthetics, but they do not subordinate themselves to metropolitan culture or petition it "for approval" (Rezek 4, 14). Nor does their work undertake the literary equivalent of what Eaton describes as visual art's attempt to "provincialize metropolitan taste" by bringing Britain to India ("Nostalgia" 243). Anglophone authors sought acclaim within their own self-devised domains, existing in between the world structure of literature (Casanova 81) and the "zigzagging movements" of nonnational literary networks (Levine 657).

If there was an "Anglicization" of British India during the late eighteenth century by which "overseas subjects" maintained a "free association" with the "mother country," as the empire historian H. V. Bowen argues (103), there was an Indianization as well, as AngloIndian norms recast or departed explicitly from metropolitan progenitors. The three authors I have examined often celebrated their region by creating ostentatious examples of 
cultural and translocal mixing, such as Candidus's ghazal translations, Irwin's portable reputation, and Romney's "oriental traits," white satis, and "big" "Muse." Anglo-Indian literature could not exist without Britain's colonization of India, of course, but this literature was not the home nation's arts annex or British culture's indigent dependent.

Rewriting literary histories to reflect the complex relation of imitation and independence between Britain and early Anglo-India would require that we dedicate more attention to the material apparatus and translocal imaginations found in multilingual writing practices, newspaper reading publics, and coterie manuscript distribution. We would consider how governmental systems and legal regulations, such as print censorship, not only specify contests over ostensibly universal notions, such as freedom of the press or civil society, but also map colonial publics' physical components and interlocking parts. A better account of the patronage and censorship of the cultural company-state is crucial if scholars are to comprehend Anglo-Indian writing as originating from local and regional concerns, and not just the expression of British national identity or of Western European colonial discourses that arose alongside modernity's rampant globalization.

Anglo-Indian authors exemplify the need for these interventions because national designations_-"British," for example-have frequently acted as frictionless ways for scholars to assume shared habits of consumption and aesthetic mentalities among peoples in enormously different locations, geographies, and life circumstances. ${ }^{23}$ If they published in London, as Irwin did, they are perceived as being an extension of its values rather than local ones. But if their audience comprised AngloIndia, as Romney's did, they are excluded from the English canon that has been fashioned since the early twentieth century. They are rarely recognized as a diaspora and thus resist its tactics of community retrieval. Program- ming literary history through vectors of nation and authenticity has had an especially strong exclusionary effect on Anglo-Indian authors: their work lacks the telos of nation-formation, which was available to American literature, and so they are seldom integrated into the national traditions that for decades organized the discipline of literary studies. The preoccupation with influence has caused scholars to neglect authors like Irwin and Romney, whose innovations appear in subject matter or political stance, in favor of more obvious formal experimenters like Jones. These authors' neglect has been exacerbated by their limited number of readers, as well as by the practical difficulties of researching archives that have been poorly preserved or only recently digitized, reasons that point to the timeliness of retrieving them for scholarly attention.

These difficulties make Anglo-Indian writing a worthy beneficiary of postcolonialism's impulse to recover significant yet obscured portions of the imperial archive. Anglo-India's forgotten authors remind us that authorial recovery can reinforce unspoken, preexisting aesthetic judgments that were the reason many writers were omitted from the canon in the first place. They reveal that literary criticism generally integrates previously neglected authors either by conferring on them the status of genius and canonicity they are presumed to have warranted all along (e.g., Aphra Behn) or by reading them as representative of "popular" topics and genres only identified retroactively (e.g., working-class poetry). Rather than accept this restrictive binary, we might instead compose literary histories that valorize competent authors whose writing, while formally conventional, nonetheless offers insights about the social questions of understudied groups, like late-eighteenth-century Anglo-Indians. Such a project would require us to track the coherent aesthetics of unheeded works that were determined only later to be the dead ends of literary history. It would bring back 
into visibility authors obscured in the "great unread" of the imperial archive and would weigh the status of culture's dark matter, which resonates with and lends mass to human production but endures only faintly in our fuzzy memory (Cohen 23).

\section{NOTES}

My thanks go to Dave Alff, Hillary Chute, Nikki Hessell, and Benjy Kahan, who read earlier versions of this essay. I also thank the American Council of Learned Societies' Frederick Burkhardt Residential Fellowship and the National Humanities Center, both of which provided funding, space, and time for the initial composition of this article. My appreciation goes to the National Humanities Center's library staff-Brooke Andrade, Sarah Harris, and Joe Milillo-who helped me research this article and acquire some of its images. Thanks also go to the staff of the British Library and the Australian Defence Force Academy Library, in Canberra, Australia, for assistance with the archives of James Romney, and to the Senate House Library, University of London, for assistance with the archives of Eyles Irwin.

1. For central descriptions of Anglo-Indian composition, see Teltscher; Chatterjee; Gibson; Joseph; Franklin, "'Hastings Circle"; Kaul. For discussions on overthrowing exilic identities, see Moore-Gilbert; Gibson; White. For archival and print histories, see Shaw, Printing; Ogborn.

2. Scholarship on the Indian Ocean has grown substantially since the 1990s. For a detailed bibliography, see Hofmeyr et al.

3. I use Anglo-Indian to mean white inhabitants of India, rather than people of mixed race, the definition that emerged in the nineteenth century. For information on this redefinition, see S. Ghosh 57.

4. P. J. Marshall, a noted historian of India, for example, concluded in 1990 that while colonists in North America, Australasia, and the Caribbean developed identities that melded their British heritage with the culture of the places they settled, "no clear British-Indian identity ever emerged" among the British colonists in India, because it was a "community dominated by official employment, recruited in Britain and set on returning to Britain" ("Whites" 26-27). Clark claims the British residents of Calcutta, Madras, and Bombay comprised "small elite cadres" (425-26) that formed a "cultural ghetto" (428), even though the white population of each of these cities was equivalent to that of a British market town. The cultural importance of this significant British presence has been recognized by social historians but largely ignored by literary scholars (Chandler 171).
5. Historians have argued that India was the "subimperial center" of a regional network connected to a larger European dominion (Ballantyne 35; Metcalf 7-8). For critical regionalism's scholarly migration from architecture studies to social science and the humanities, see Frampton; Powell; Spivak. Regionalism has always been redefined by debates about locality (Massey, Space; Hardt and Negri 43-46; Hsu).

6. Limón understands critical regionalism as interceding between local and global.

7. For more on these crucial decades, see Bayly, Indian Society 7-44; Marshall, Bengal 93-172 and Making 207-72; Richards 253-81.

8. The phrase "cultural company-state" combines two interventions in understandings of the EIC and statesupported cultural production. Stern suggests that the EIC was a "company-state," a "form of political community and polity" that pursued many of the same functions as nation-states (10), while Hoock describes the British "cultural state" (17) that advanced national interests in concert with the fiscal-military state described by Brewer. For more on the EIC as a company-state in the eighteenth century, see Sen xxv, 1; Stern 207-14.

9. Estimates differ on the amount of the British book trade that involved India, but it increased substantially during the late eighteenth century. Barber suggests that book exports to India accounted for ten percent of all exports in 1750 but nineteen percent by 1773 ("Books" 203, 218; “Book Imports" 101).

10. Additional information on pandits and orientalists can be found in Rocher, "Weaving." See Raj, "Refashioning," for information about maulvis (183-85) and Alam and Subrahmanyam for the importance of munshis (420).

11. Raman focuses on nineteenth-century southern Indian native scribes whose work made that empire function. There was never a consistent civil apparatus, however, since individual self-interest often led to disagreement about how to administer empire (14-15).

12. Some evidence exists that a London printer, Henry Hill, operated briefly in Bombay in 1674-75 before returning to England, though it is still inconclusive (Errington 8).

13. For more on Khusrau, see Losensky; Schimmel.

14. The presidencies were locations of EIC governance. Calcutta, Madras, and Bombay were the prominent presidencies of eighteenth-century India.

15. Rodrigues estimates there were one thousand people with European origins or ancestors in 1789 Bombay among a total population of 100,000 (193).

16. James Romney was the great uncle of Miles Romney, who converted to Mormonism, traveled to America, and was the great-great-grandfather of Mitt Romney (Hebblethwaite).

17. Romney's archive contains a collection of letters he received in Tamil, implying knowledge of that language. 
18. The occasion of these letters is not clear. The use of a pseudonym suggests publication in venues like newspapers, but personal references in some letters suggest private correspondence.

19. Metropolitical is synonymous with metropolitan (though it also has a religious definition: "Of, belonging to, or designating a metropolitan see or bishop" ["Metropolitical"]).

20. Bakhle suggests the Bombay Theater was founded in 1770 (86). Dwyer and Patel suggest it was 1776 and refer to it as the "Bombay Amateur Theater" (14).

21 . The play is preserved in a two-act version (called Oriental Traits) and a five-act form. I have drawn from the five-act version.

22. Although there was pervasive worry about Britain's being overrun with rich nabobs returning from India, the historical record seems to show that few EIC employees became wealthy and left India. Of the 508 British civil servants living in Bengal between 1762 and 1784, for example, only thirty-seven returned to Britain (Misra 52).

23. Contrast this with Tsing's idea that friction mobilizes adherents to universal ideas that nonetheless are enacted locally (7-8).

\section{Works Cited}

A. "To the Editor of The Calcutta Gazette." The Calcutta Gazette; or, Oriental Advertiser, 8 Feb. 1787, p. 2.

Ahmed, Siraj. The Stillbirth of Capital: Enlightenment Writing and Colonial India. Stanford UP, 2012.

Alam, Muzaffar, and Sanjay Subrahmanyam. "Witnesses and Agents of Empire: Eighteenth-Century Historiography and the World of the Mughal Munshi." Journal of Economic and Social History of the Orient, vol. 53, 2010, pp. 393-423.

Anderson, Benedict. Imagined Communities: Reflections on the Origin and Spread of Nationalism. Verso, 1983.

Anderson, Misty G. Female Playwrights and EighteenthCentury Comedy: Negotiating Marriage on the London Stage. Palgrave Macmillian, 2002.

Appadurai, Arjun. Modernity at Large: Cultural Dimensions of Globalization. U of Minnesota P, 1996.

Archer, Mildred. India and British Portraiture, 17701825. Sotheby Parke Bernet, 1979.

Bakhle, Janaki. Two Men and Music: Nationalism in the Making of an Indian Classical Tradition. Oxford UP, 2005.

Ballantyne, Tony. Orientalism and Race: Aryanism in the British Empire. Palgrave Macmillan, 2002.

Banerjee, Subhabrata Bobby. "Voices of the Governed: Towards a Theory of the Translocal." Organization, vol. 18, no. 3, 2011, pp. 323-44.

Barber, Giles. "Book Imports and Exports in the Eighteenth Century." Sale and Distribution of Books from
1700, edited by Robin Myers and Michael Harris, Oxford Polytechnic, 1982, pp. 77-105.

. "Books from the Old World and for the New: The British International Trade in Books in the Eighteenth Century." Studies on Voltaire and the Eighteenth Century, no. 151, 1976, pp. 185-224.

Barns, Margarita. The Indian Press: A History of the Growth of Public Opinion in India. George Allen and Unwin, 1940.

Bauer, Thomas, and Angelika Neuwirth. Introduction. Ghazal as World Literature I: Transformations of a Literary Genre, edited by Bauer and Neuwirth, Ergon Verlag Würburg, 2005, pp. 9-31.

Bayly, C. A. Empire and Information: Intelligence Gathering and Social Communication in India, 1780-1870. Cambridge UP, 1996.

Indian Society and the Making of the British Empire. Cambridge UP, 1990.

Blackburn, Stuart. Print, Folklore, and Nationalism in Colonial South India. Permanent Black, 2003.

Bowen, H. V. Elites, Enterprise, and the Making of the British Overseas Empire, 1688-1775. Palgrave Macmillan, 1996.

Brewer, John. The Sinews of Power: War, Money, and the English State, 1688-1783. Harvard UP, 1988.

Brickell, Katherine, and Ayona Datta. "Translocal Geographies.” Introduction. Translocal Geographies: Spaces, Places, Connections, edited by Brickell and Datta, Ashgate, 2011, pp. 3-22.

Bunyan, John. The Pilgrim's Progress. Vepery, Office of the Mission, 1793.

Candidus. "I told my friend, in artless lay." Madras Courier, 28 July 1790.

- "An Ode on the Introduction of the Cold Weather." The Calcutta Gazette; or, Oriental Advertiser, 4 Nov. 1784 , p. 3.

. "An Ode: Translated from Anacreon." The Calcutta Gazette; or, Oriental Advertiser, 18 Nov. 1784, p. 2.

. "A Song of Amir Khoseru." The Calcutta Gazette; or, Oriental Advertiser, 16 Dec. 1784, p. 2.

_. "Verses Addressed to a Lady in England." Madras Courier, 25 Aug. 1791.

Casanova, Pascale. "Literature as a World." New Left Review, no. 31, Jan.-Feb. 2005, pp. 71-90.

Chandler, David. “'The Athens of England': Norwich as a Literary Center in the Late Eighteenth Century." Eighteenth-Century Studies, vol. 43, no. 2, 2010, pp. 171-92.

Chatterjee, Amal. Representations of India, 1740-1840: The Creation of India in the Colonial Imagination. St. Martin's Press, 1998.

Chen, Kuan-Hsing. Asia as Method: Toward Deimperialization. Duke UP, 2010.

Clark, Peter. British Clubs and Societies, 1580-1800. Clarendon Press, 2000. 
Clifford, James. Routes: Travel and Translation in the Late Twentieth Century. Harvard UP, 1997.

Cohen, Margaret. The Sentimental Education of the Novel. Princeton UP, 1999.

Cohn, Bernard. Colonialism and Its Forms of Knowledge: The British in India. Princeton UP, 1996.

Darnton, Robert. Censors at Work: How States Shaped Literature. W. W. Norton, 2014.

Datta, Kitty Scoular. "Publishing and Translating Hafez under Empire." Books without Borders, edited by Robert Fraser and Mary Hammond, Palgrave Macmillan, 2008, pp. 58-70. Vol. 2 of Perspectives from South Asia.

de Bruijn, J. T. P. “Ḡazal i. History.” Encyclopaedia Iranica, www.iranicaonline.org/articles/gazal-1-history.

DeWispelare, Daniel. Multilingual Subjects: On Standard English, Its Speakers, and Others in the Long Eighteenth Century. U of Pennsylvania P, 2017.

Dharwadker, Vinay. "Print Culture and Literary Markets in Colonial India." Language Machines: Technologies of Literary and Cultural Production, edited by Jeffrey Masten et al., Routledge, 1997, pp. 108-33.

Doyle, Laura. "Inter-imperiality and Literary Studies in the Longer Durée." PMLA, vol. 130, no. 2, Mar. 2015, pp. 336-47.

Duncan, Jonathan. "Part of a Letter from Jonathan Duncan, Resident at Benares, to Earl Cornwallis, GovernorGeneral in Council of Fort William in Bengal, Dated 1 January 1792." Zastoupil and Moir, pp. 77-80.

Dwyer, John. "Enlightened Spectators and Classical Moralists: Sympathetic Relations in Eighteenth-Century Scotland." Eighteenth-Century Life, vol. 15, nos. 1-2, 1991, pp. 96-118.

Dwyer, Rachel, and Divia Patel. Cinema India: The Visual Culture of Hindi Film. Rutgers UP, 2002.

Eaton, Natasha. Mimesis across Empires: Artworks and Networks in India, 1765-1860. Duke UP, 2013.

_. "Nostalgia for the Exotic: Creating an Imperial Art in London, 1750-1793." Eighteenth-Century Studies, vol. 39, no. 2, Winter 2006, pp. 227-50.

Eisenstadt, Shmuel N. "Multiple Modernities.” Multiple Modernities. 2002. Edited by Eisenstadt, Routledge, 2017, pp. 1-29.

Errington, Joseph. Exotic Printing and the Expansion of Europe, 1492-1840: An Exhibit. Lilly Library, Indiana $U, 1972$.

Foote, Samuel. The Nabob. Dublin, 1778.

Frampton, Kenneth. "Towards a Critical Regionalism: Six Points for an Architecture of Resistance." The Anti-Aesthetic: Essays on Postmodern Culture, edited by Hal Foster, Bay Press, 1983, pp. 16-30.

Franklin, Michael J. “'The Hastings Circle': Writers and Writing in Calcutta in the Last Quarter of the Eighteenth Century." Authorship, Commerce, and the Public: Scenes of Writing, 1750-1850, edited by E. J. Clery et al., Palgrave Macmillan, 2002, pp. 186-202.
. Introduction. Hartly House, Calcutta, edited by Franklin, Oxford UP, 2008, pp. xi-lvii.

Fraser, Robert. Book History through Postcolonial Eyes: Rewriting the Script. Routledge, 2008.

Freeman, Lisa A. Character's Theater: Genre and Identity on the Eighteenth-Century English Stage. U of Pennsylvania $\mathrm{P}, 2002$.

Freitag, Ulrike, and Achim von Oppen. “Translocality”: An Approach to Connection and Transfer in Area Studies." Translocality: The Study of Globalising Processes from a Southern Perspective, edited by Freitag and Oppen, Brill, 2010, pp. 1-21. Studies in Global Social History 4.

Gabbay, A. "Chapter 1: Establishment of Centers of IndoPersian Court Poetry." Persian Literature from outside Iran: The Indian Subcontinent, Anatolia, Central Asia, and in Judeo-Persian, edited by John R. Perry, I. B. Tauris, 2018, pp. 3-47. Vol. 9 of A History of Persian Literature.

Geertz, Clifford. "Local Knowledge: Fact and Law in Comparative Perspective." Local Knowledge: Further Essays in Interpretive Anthropology, Basic Books, 1983, pp. 167-234.

Ghosh, Anindita. "Literary Traditions in Pre-print Bengal and Their Legacy in the Age of Print." On Modern Indian Sensibilities: Culture, Politics, History, edited by Ishita Banerjee-Dube and Sarvani Gooptu, Routledge, 2018, pp. 234-58.

- Power in Print: Popular Publishing and the Politics of Language and Culture in a Colonial Society, 17781905. Oxford UP, 2006.

Ghosh, Suresh. The Social Condition of the British Community in Bengal, 1757-1800. Brill, 1970.

Gibson, Mary Ellis. Indian Angles: English Verse in Colonial India from Jones to Tagore. Ohio UP, 2011.

Greiner, Clemens, and Peter Sakdapolark. "Translocality: Concepts, Applications, and Emerging Research Perspectives." Geography Compass, vol. 7, no. 5, May 2013, pp. 373-84.

Griswold, Wendy. Regionalism and the Reading Class. U of Chicago P, 2008.

Halhed, Nathaniel Brassey. A Grammar of the Bengal Language. Hoogly, 1778.

Hall, Kenneth R. “The Eighteenth- and Early NineteenthCentury Evolution of Indian Print Culture and Knowledge Networks in Calcutta and Madras." Print Culture Histories beyond the Metropolis, edited by James J. Connolly et al., U of Toronto P, 2016, pp. 88-122.

Hannerz, Ulf. Transnational Connections: Culture, People, Places. Routledge, 1996.

Hardt, Michael, and Antonio Negri. Empire. Harvard UP, 2000.

Harrison, Mark. "Networks of Knowledge: Science and Medicine in Early Colonial India, c. 1750-1820." India and the British Empire, edited by Douglas Peers and N. Gooptu, Oxford UP, 2012, pp. 191-212. 
Hastings, Warren. "Minute by Warren Hastings, GovernorGeneral of Fort William (Calcutta) in Bengal, Recorded in the Public Department, 17 April 1781." Zastoupil and Moir, pp. 73-76.

Hebblethwaite, Cordelia. "Mitt Romney's Mormon Roots in Northern England." BBC News, 13 June 2012, www .bbc.com/news/magazine-18422949.

Hevia, James. Cherishing Men from Afar: Qing Guest Ritual and the McCartney Embassy of 1793. Duke UP, 1995.

[Hicky, James Augustus]. “The Printer's Solilqui.” Hicky's Bengal Gazette, 16 Dec. 1780.

Hilton, John. "Speaking Truth to Power: Julian, the Cynics and the Ethiopian Gymnosophists of Heliodorus." Intellectual and Empire in Greco-Roman Antiquity, edited by Philip R. Bosman, Routledge, 2019, pp. 202-15.

Hofmeyr, Isabel. "The Globe in the Text: Towards a Transnational History of the Book." African Studies, vol. 64 , no. 1,2005 , pp. $87-103$.

- The Portable Bunyan: A Transnational History of The Pilgrim's Progress. Princeton UP, 2004.

Hofmeyr, Isabel, et al. "Print Cultures, Nationalisms, and Publics of the Indian Ocean." Introduction. Africa, vol. 81, no. 1, 2011, pp. 1-22.

Hoock, Holger. Empires of Imagination: Politics, War, and the Arts in the British World. Profile Books, 2010.

Hsu, Hsuan. "Literature and Regional Production." American Literary History, vol. 17, no. 1, Spring 2005, pp. 36-69.

Irwin, Eyles. Bedukah; or, The Self-Devoted: An Indian Pastoral: By the Author of Saint Thomas's Mount. London, 1776.

- Continuation of a Review Concerning Kolastri. Circa 1782-87, British Library, London, India Office Records H/328.

__ " "Ode to the Nile." India Gazette; or, Calcutta Public Advertiser, no. 32, 23 June 1781.

"Prologue, Written for the Opening of the Lyceum at Madras 1782, spoken by Major Maule." Senate House Library, University of London, MS 704.

__. "Ramah; or, The Bramin." Eastern Eclogues: Written during a Tour through Arabia, Egypt, and Other Parts of Asia and Africa in the Year MDCCLXXVII, London, 1780, pp. 19-25.

- Report on the Tinevelly Revenue System. 23 Apr. 1783, British Library, London, India Office Records $\mathrm{H} / 258$.

- Saint Thomas's Mount: A Poem: Written by a Gentleman in India. London, 1774.

."To Mrs. Charlotte Smith, on Her Various Works." The Gentleman's Magazine, vol. 64, Nov. 1794, p. 1035.

—. To William Hayley. 20 Apr. 1784. Fitzwilliam Museum, U of Cambridge, Hayley Letters 9.

Jones, William. A Grammar of the Persian Language. London, 1771.
Joseph, Betty. Reading the East India Company, 1720-1840: Colonial Currencies of Gender. U of Chicago P, 2004.

Joshi, Priya. In Another Country: Colonialism, Culture, and the English Novel in India. Columbia UP, 2002.

Juncu, Meera. India in the Italian Renaissance: Visions of a Contemporary Pagan World, 1300-1600. Routledge, 2016.

Kanda, K. C. Urdu Ghazals: An Anthology from Sixteenth to Twentieth Century. Sterling, 1995.

Katz, Daniel. American Modernism's Expatriate Scene: The Labour of Translation. Edinburgh UP, 2007.

Kaul, Suvir. "English Poetry in India: The Early Years." A History of Indian Poetry in English, edited by Rosinka Chaudhuri, Cambridge UP, 2016, pp. 32-47.

Kaviraj, Sudipta. "An Outline of a Revisionist Theory of Modernity." European Journal of Sociology / Archives européennes de sociologie, vol. 46, no. 3, 2005, pp. 497526.

Kesavan, B. S. South Indian Origins of Printing. National Book Trust, 1984. Vol. 1 of History of Printing and Publishing in India: A Story of Cultural Re-awakening.

Keymer, Thomas. Sterne, the Moderns, and the Novel. Oxford UP, 2002.

Khan, M. Siddiq. "The Early Bengali Printed Books." Gutenberg-Jahrbuch, 1966, pp. 200-08.

Knowles, Claire. Sensibility and the Female Poetic Tradition, 1780-1860: The Legacy of Charlotte Smith. Ashgate, 2009.

Kopf, David. British Orientalism and the Bengal Renaissance: The Dynamics of Indian Modernization, 17731835. U of California P, 1969.

Kraidy, Marwan M., and Patrick D. Murphy. "Shifting Geertz: Toward a Theory of Translocalism in Global Communication Studies." Communication Theory, vol. 18, 2008, pp. 335-55.

Levine, Caroline. "From Nation to Network." Victorian Studies, vol. 55, no. 4, Summer 2013, pp. 647-66.

Limón, José E. “Borders, Literary Histories, Globalization, and Critical Regionalism." American Literary History, vol. 20, 2008, pp. 160-82.

Little, Nigel. Transoceanic Radical, William Duane: National Identity and Empire, 1760-1835. Pickering and Chatto, 2008.

Lockyer, Dora. "The Provision of Books and Libraries by the East India Company in India, 1611-1858.” 1977. Library Association Fellow thesis, British Library, London, Mss Eur Photo Eur 153.

Losensky, Paul E. "Linguistic and Rhetorical Aspects of the Signature Verse (Takhallus) in the Persian Ghazal." Edebiyât: Journal of Middle Eastern Literature, vol. 8, no. 2, June 1998, pp. 239-71.

Love, H. D. Vestiges of Old Madras, 1600-1800. Vol. 3. John Murray, 1913.

Lowenthal, Cynthia. Performing Identities on the Restoration Stage. Southern Illinois UP, 2003. 
Mandaville, Peter G. “Territory and Translocality: Discrepant Idioms of Political Identity." Millennium: A Journal of International Studies, vol. 28, no. 3, 1999, pp. 653-73.

Marshall, P. J. Bengal: The British Bridgehead: Eastern India, 1740-1828. Cambridge UP, 1987.

- The Making and Unmaking of Empires: Britain, India, and America, c. 1750-1783. Oxford UP, 2008.

__. "Warren Hastings as Scholar and Patron." Statesmen, Scholars, and Merchants: Essays in EighteenthCentury History Presented to Dame Lucy Sutherland, edited by Anne Whiteman et al., Clarendon Press, 1973, pp. 242-62.

_ . "The Whites of British India, 1780-1830: A Failed Colonial Society?” The International History Review, vol. 12, no. 1, Feb. 1990, pp. 26-44.

Massey, Doreen. Power-Geometries and the Politics of Space-Time: Hettner Lecture 1998. Dept. of Geography, U of Heidelberg, 1999.

- Space, Place, and Gender. U of Minnesota P, 1994.

McFarlane, Colin. "Translocal Assemblages: Space, Power, and Social Movements." Geoforum, vol. 40, no. 44, 2009, pp. 561-67.

Mee, John. Conversable Worlds: Literature, Contention, and Community, 1762 to 1830. Oxford UP, 2011.

"Memoirs of Eyles Irwin, Esq." European Magazine, no. 15, Mar. 1789, pp. 179-81.

Metcalf, Thomas R. Imperial Connections: India in the Indian Ocean Arena, 1860-1920. U of California P, 2007.

"Metropolitical, Adj." Oxford English Dictionary, www .oed.com/view/Entry/117714? redirected From = metropolitical\#eid.

Misra, B. B. The Bureaucracy in India: An Historical Analysis of Development up to 1947. Oxford UP, 1977.

Moore-Gilbert, Bart, editor. Writing India, 1757-1990: The Literature of British India. Manchester UP, 1996.

"Necessary Expense of Fitting Out a Lad for the East Indias." Circa 1780s, British Library, London, Add MS 35918, folio 222.

Nechtman, Tillman W. Nabobs: Empire and Identity in Eighteenth-Century Britain. Cambridge UP, 2010.

Nussbaum, Felicity. Torrid Zones: Maternity, Sexuality, and Empire in Eighteenth-Century English Narratives. Johns Hopkins UP, 1995.

Ogborn, Miles. Indian Ink: Script and Print in the Making of the English East India Company. U of Chicago P, 2007.

Orsini, Francesca. "The Multilingual Local in World Literature." Comparative Literature, vol. 67, no. 4, 2015, pp. 345-74.

Orsini, Francesca, et al. "Multilingual Locales and Textual Circulation." Introduction. Comparative Studies of South Asia, Africa, and the Middle East, vol. 39, no. 1, May 2019, pp. 63-67.
Pollock, Sheldon. The Language of the Gods in the World of Men: Sanskrit, Culture, and Power in Premodern India. U of California P, 2006.

- "The Sanskrit Cosmopolis, A.D. 300-1300: Transculturation, Vernacularization, and the Question of Ideology." The Ideology and Status of Sanskrit in South and Southeast Asia, edited by J. E. M. Houben, Brill, 1996, pp. 197-247.

Potter, S. J. News and the British World: The Emergence of an Imperial Press System, 1876-1922. Clarendon Press, 2003.

Powell, Douglas Reichert. Critical Regionalism: Connecting Politics and Culture in the American Landscape. U of North Carolina P, 2007.

Prior, D. L. “Irwin, Eyles (Bap. 1751, D. 1817).” Oxford Dictionary of National Biography, Oxford UP, 2020, doi.org/10.1093/ref:odnb/14477.

"Proclamation." The Calcutta Gazette; or, Oriental Advertiser, 24 Feb. 1785, p. 2.

Qayyum, Mohammad Abdul. A Critical Study of Early Bengali Grammars. Asiatic Society of Bangladesh, 1982.

Raj, Kapil. "Refashioning Civilities, Engineering Trust: William Jones, Indian Intermediaries, and the Production of Reliable Legal Knowledge in Late-EighteenthCentury Bengal." Studies in History, vol. 17, no. 2, 2001, pp. 175-209.

- Relocating Modern Science: Circulation and the Construction of Knowledge in South Asia and Europe, 1650-1900. Palgrave Macmillan, 2007.

Raman, Bhavani. Document Raj: Writing and Scribes in Early Colonial South India. U of Chicago P, 2012.

Ramazani, Jahan. "The Local Poem in a Global Age.” Critical Inquiry, vol. 43, no. 3, Spring 2017, pp. 670-96.

—. A Transnational Poetics. U of Chicago P, 2009.

Raposo, Pedro M. P., et al. "Moving Localities and Creative Circulation: Travels as Knowledge Production in Eighteenth-Century Europe." Centaurus, vol. 56, 2014, pp. 167-88.

"Restrictions on the Press in India." 1791-1820, British Library, London, India Office Records H/537.

Rezek, Joseph. London and the Making of Provincial Literature: Aesthetics and the Transatlantic Book Trade, 1800-1850. U of Pennsylvania P, 2015.

Rhodes, Dennis. The Spread of Printing: The Eastern Hemisphere: India, Pakistan, Ceylon, Burma, Thailand. Van Gendt, 1969.

Richards, John F. The Mughal Empire. Cambridge UP, 1993.

Rocher, Rosane. Orientalism, Poetry, and the Millennium: The Checkered Life of Nathaniel Brassey Halhed, 17511830. Motilal Banarsidass, 1983.

_. "Weaving Knowledge: Sir William Jones and the Indian Pandits." Objects of Inquiry: The Life, Contribution, and Influences of Sir William Jones, 1746- 
1794, edited by Garland Cannon and Kevin R. Brine, New York UP, 1994, pp. 51-91.

Rodrigues, Dulcinea Correa. Bombay Fort in the Eighteenth Century. Himalaya Publishing House, 1994.

Romney, James. "Mr. Editor.” Circa 1790s, British Library, London, MSS Eur F198/3/2, folio 9-13.

__. "My Dear Sir." 10 July 1802. British Library, London, Mss Eur F198/3/6.

. "Pages from a Five Act Play (Includes All of Acts 3 and 5, Part of Acts 2 and 4)." Circa 1780s-1790s, British Library, London, MSS Eur F198/4/29.

- The Pavilion: A Comedy in Five Acts. Circa 1780s1790s, British Library, London, MSS Eur F198/4/31.

__. "Sager! Gymnosophisto! what are your names." Circa 1770s-1790s, British Library, London, MSS Eur F198/5/3.

—_. "To Mrs. Town.” 19 Nov. 1793. British Library, London, MSS Eur F198/3/3.

—. "To the Editor of the Bombay Gazzett." Circa 1790s, British Library, London, MSS Eur F198/3/2, folios 14-15.

Rosenthal, Laura J. Playwrights and Plagiarists in Early Modern England: Gender, Authorship, Literary Property. Cornell UP, 1996.

Ross, Fiona G. E. The Printed Bengali Character and Its Evolution. Curzon Press, 1999.

Schimmel, A. “Amīr Kosrow Dehlavī.” Encyclopaedia Iranica, www.iranicaonline.org/articles/amir-kosrow -poet.

Schürer, Norbert. "The Impartial Spectator of Sati, 17571784.” Eighteenth-Century Studies, vol. 42, no. 1, 2008, pp. 19-44.

Secord, James. "Knowledge in Transit." Isis, vol. 95, no. 4, Dec. 2004, pp. 654-72.

Sen, Sudipta. Distant Sovereignty: National Imperialism and the Origins of British India. Routledge, 2002.

Senex. "The Monitor." India Gazette; or, Calcutta Public Advertiser, no. 5, 16 Dec. 1780.

Sharma, Arvind, et al. Sati: Historical and Phenomenological Essays. Motilal Banarsidass, 1988.

Sharma, Sunil. Amir Khusraw: The Poet of Sultans and Sufis. Oneworld, 2005.

Shaw, Graham. "The British Book in India." The Cambridge History of the Book in Britain. Vol. 5 (16951830), edited by Michael F. Suarez and Michael L. Turner, Cambridge UP, 1998, pp. 560-75.

_ . "From Goa to the Gutenberg Award: The Story of Indian Typography." Typo: Typografie, grafický design, vizuální komunikace / Typography, Graphic Design, Visual Communication, vol. 49, Autumn 2012, pp. 8-15.

. "India." Ambition and Industry, 1800-1880, edited by Bill Bell, Edinburgh UP, 2007, pp. 456-64. Vol. 3 of The Edinburgh History of the Book in Scotland.
Printing in Calcutta to 1800: A Description and Checklist of Printing in Late Eighteenth-Century Calcutta. Bibliographical Society, 1981.

- The South Asia and Burma Retrospective Bibliography (SABREB). Stage 1 (1556-1800), British Library, 1987.

Sinha, Mrinalini. "Britishness, Clubbability, and the Colonial Public Sphere: The Genealogy of an Imperial Institution in Colonial India." Journal of British Studies, vol. 40, no. 4, 2001, pp. 489-521.

Smith, Michael Peter. "Power in Place / Places of Power: Contextualizing Transnational Research." City and Society, vol. 17, no. 1, 2005, pp. 5-34.

Spear, Percival. The Nabobs: A Study of the Social Life of the English in Eighteenth-Century India. Oxford UP, 1963.

Spivak, Gayatri Chakravorty. Other Asias. Blackwell Publishing, 2008.

Steadman, J. M. "The Asiatick Society of Bengal." Eighteenth-Century Studies, vol. 10, no. 4, 1977, pp. 464-83.

Stern, Philip J. The Company-State: Corporate Sovereignty and the Early Modern Foundations of the British Empire in India. Oxford UP, 2011.

Sterne, Laurence. The Life and Opinions of Tristram Shandy, Gentleman. 1761-67. Edited by Ian Campbell Ross, Oxford UP, 1983.

Stoler, Ann Laura, and Frederick Cooper. "Between Metropole and Colony: Rethinking a Research Agenda." Tensions of Empire: Colonial Cultures in a Bourgeois World, edited by Cooper and Stoler, U of California P, 1997, pp. 1-56.

Subrahmanyam, Sanjay. "Connected Histories: Notes toward a Reconfiguration of Early Modern Eurasia." Modern Asian Studies, vol. 31, no. 3, 1997, pp. 735-62.

Teltscher, Kate. India Inscribed: European and British Writing on India, 1600-1800. Oxford UP, 1995.

Truschke, Audrey. Culture of Encounters: Sanskrit at the Mughal Court. Columbia UP, 2016.

Tsing, Anna Lowenhaupt. Friction: An Ethnography of Global Connection. Princeton UP, 2005.

Viswanathan, Gauri. Masks of Conquest: Literary Study and British Rule in India. Columbia UP, 1989.

Warner, Michael. Letters of the Republic: Publication and the Public Sphere in Eighteenth-Century America. Harvard UP, 1990.

White, Daniel E. From Little London to Little Bengal: Religion, Print, and Modernity in Early British India, 1793-1835. Johns Hopkins UP, 2013.

Wilson, Kathleen. The Sense of the People: Politics, Culture, and Imperialism in England, 1715-1785. Cambridge UP, 1995.

Zastoupil, Lynn, and Martin Moir, editors. The Great Indian Education Debate: Documents Relating to the OrientalistAnglicist Controversy, 1781-1843. Curzon, 1999. 